Ks. Stanisław LONGOSZ

(Lublin, KUL)

\title{
RODZINA KOŚCIOLEM DOMOWYM W MYŚLI ŚW. JANA CHRYZOSTOMA
}

Przy omawianiu familijno-pedagogicznej problematyki w nauczaniu św. Jana Chryzostoma (350-407), wielkiego duszpasterza, biskupa i patriarchy Konstantynopola (397-407), nie można również pominąć tego, że on po raz

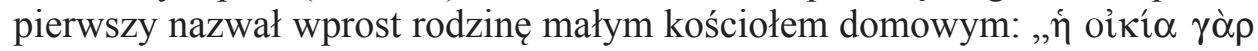

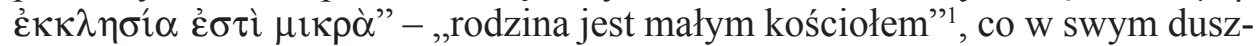
pasterstwie wielokrotnie powtarzał. Przez tę nazwę chciał zapewne wyrazić swoje pragnienie z jednej strony przeniesienia do rodziny chrześcijańskiej atmosfery kościoła, w którym oficjalnie praktykowano modlitwę oraz czytano i rozważano słowo Boże, a z drugiej uaktywnienia w niej roli ojca, także w przekazywaniu tych religijnych treści. Nazwa ta znajdowała, bez wątpienia, swe uzasadnienie w Piśmie Świętym Nowego Testamentu, zwłaszcza w Dziejach Apostolskich i Listach św. Pawła, które on szczegółowo systematycznie wszystkie komentował, a także w wielowiekowej tradycji rodziny starożytnej, zarówno grecko-rzymskiej, w której pater familias był m.in. również kapłanem odpowiedzialnym za domowe modlitwy i ofiary (sacra) oraz za kult bóstw rodzinnych i kult przodków (cultus maiorum), jak i żydowskiej, w której ojciec przewodniczył, zwłaszcza podczas Paschy, domowym modlitwom, komentował Biblię i pouczał religijnie swoich domowników. Jan Chryzostom, który obok św. Augustyna na Zachodzie, najobszerniej z Ojców Kościoła wypowiedział się na temat wczesnochrześcijańskiego małżeństwa, rodziny i wy-

\footnotetext{
${ }^{1}$ In epistulam ad Ephesios hom. 20, 6, PG 62, 143, BOK 19, 60; zob. J. Höffner, „,Euer Haus sei eine Kirche”. Der hl. Chrysostomus über das Apostolat der Eltern, „Die Kinderseelsorge” 5 (1938) 40-41; C. Scaglioni, Ideale coniugale e familiare in Giovanni Crisostomo, w: Etica sessuale e matrimonio nel cristianesimo delle origini, ed. R. Cantalamessa, Milano 1976, 419-422 (La famiglia è una piccola chiesa); E. Lodi, Famiglia-Chiesa domestica nella tradizione patristica, „Rivista di Pastorale Liturgica” 18 (1980) nr 5, 25-30; P. Rentinck, La cura pastorale in Antiochia nel IV secolo, Roma 1970, 277-280 (La Chiesa domestica); A. Bober, Rodzina Kościołem domowym wedtug św. Jana Chryzostoma, VoxP 5 (1985) z. 8-9, 193-200; H. Wójtowicz, Zadania rodziny chrześcijańskiej w nauczaniu św. Jana Chryzostoma, tamże, s. 211-214 (Rodzina Kościołem domowym); S. Longosz, Rodzina wczesnochrześcijańska kościołem domowym, RT 51 (2004) 10 i 5650 (św. Jan Chryzostom).
} 
chowania ${ }^{2}$, tchnął również w pojęcie „rodzina kościołem domowym” najbogatsze treści tradycyjno-biblijne, które warto odczytać i unaocznić.

\section{GENEZA POJĘCIA „RODZINA KOŚCIOŁEM DOMOWYM”}

Wyrażenie „rodzina Kościołem domowym” ma swoje uzasadnienie i początek, jak wspominaliśmy, w Piśmie Świętym Nowego Testamentu, zwłaszcza w Dziejach Apostolskich i Listach św. Pawła ${ }^{3}$. To tam właśnie są informacje o pierwszych nawróconych rodzinach lub domach chrześcijańskich jako wspólnotach misyjnych i miejscach kultu. Słyszymy więc o nawróceniu ,pobożnego i bogobojnego wraz z całym swym domem" setnika Korneliusza, w domu którego Kościół stał się dostępny dla pogan (Dz 10, 1-11 i 24-48); o strażniku więziennym w Filippi, który ,przyjął chrzest z całym swym domem [...] i razem z całym domem cieszył się bardzo, że uwierzył w Boga" (Dz 16, 31-34); o pochodzącej z tego samego miasta sprzedawczyni purpury Lidii, „która została ochrzczona razem ze swym domem" (Dz 16, 15); o przełożonym synagogi w Koryncie Kryspusie, który „uwierzył w Pana z całym swym domem” (Dz

\footnotetext{
${ }^{2}$ Por. J. Dumortier, Le mariage dans les milieux chrétiens d'Antioche et Byzance d'après Saint Jean Chrysostome, „Lettres d'Humanité” 6 (1947) 102-166; C. Scaglioni, Ideale coniugale e familiare in San Giovanni Crisostomo, w: Etica sessuale e matrimonio nel cristianesimo delle origini, red. R. Cantalamessa, Milano 1976, 273-422; K. Tsouros, La dottrina sul matrimonio in San Giovanni Crisostomo, „Asprenas” 21 (1974) 9-46; M. José Soto, El matrimonio „, in fieri” en la doctrina de S. Ambrosio y S. Crisostomo, ThH 35, Roma 1976; T. Špidlík, Il matrimonio, sacramento di unità nel pensiero di Crisostomo, „Augustinianum” 17 (1977) 221-226; H. Wójtowicz, Zadania rodziny chrześcijańskiej w nauczaniu św. Jana Chryzostoma, VoxP 5 (1985) t. 8-9, 201-214; A. Uciecha, Rodzina miejscem wychowania $w$ traktacie pedagogicznym o wychowaniu dzieci Jana Chryzostoma, ŚSHT 19-20 (1986-1987) 65-92; C.P. Roth - D. Anderson (red.), St. John Chrysostom on marriage and family life, Crestwood NY 1986; O. Pasquato, Eredità giudaica e famiglia cristiana.La testimonianza di Giovanni Crisostomo, „Lateranum” 54 (1988) 58-91; tenże, Pastorale familiare. La testimonianza di Giovanni Crisostomo, „Salesianum”51 (1989) 3-46; tenże, I laici in Giovanni Crisostomo: tra Chiesa, famiglia e città, Roma 1998; E. Stanula, Rodzina ksztattująca system wartości w ujęciu św. Jana Chryzostoma, w: Wychowanie w rodzinie od starożytności po wiek XX. Materiały z konferencji, red. J. Jundziłł, Bydgoszcz 1993, 81-94; L. Dattrino, Giovanni Crisostomo di fronte al matrimonio, RivAC 78 (2002) 145-155; tenże, Il matrimonio nel pensiero di Giovanni Crisostomo, Roma 2002; J. Krykowski, Nauka o matżeństwie, rodzinie i wychowaniu $u$ św. Jana Chryzostoma (Wstęp), BOK 19, w: Św. Jan Chryzostom, O matzeństwie, wychowaniu dzieci i ascezie, przekład zbiorowy, Kraków 2002, 17-43; S. Kos, Matrimony as a path to salvation in the writings of St. John Chrysostom (po chorwacku), „Obnovljeni Život” 58 (2003) 43-72; P. Szczur, Problematyka społeczna w późnoantycznej Antiochii na podstawie nauczania homiletycznego Jana Chryzostoma, Lublin 2008, 293-360 (Małżeństwo i rodzina); inne zob. niżej w bibliografii: S. Longosz, Matzeństwo, rodzina i wychowanie w nauczaniu św. Jana Chryzostoma. Materiaty bibliograficzne, VoxP 29 (2009) t. 53-54, ???.

${ }^{3}$ Por. R. Banks, Paul's idea of community: the early house Churches in their historical setting, Exter 1980; D. von Almen, The famille de Dieu. Le symbolique familiale dans la paulinisme, Freiburg - Göttingen 1981 .
} 
18, 8). Św. Jan Ewangelista opowiada o nawróceniu urzędnika królewskiego w Kafarnaum, który po uzdrowieniu jego syna przez Chrystusa „uwierzył sam i cała jego rodzina" (J 4, 46-54), a św. Paweł poleca pozdrowić swoich współpracowników w Rzymie - Pryskę i Akwilę, a „także Kościół, który zbiera się w ich domu" (Rz 16, 5), gdzie indziej zaś zapewnia Koryntian, iż pozdrawiają ich „Akwila i Pryscylla razem ze zbierającym się w ich domu Kościołem” (1Kor 16, 19), albo też prosi Kolosan by pozdrowili „braci w Laodycei, zarówno Nimfasa jak i Kościół w jego domu" (Kol 4, 15). Wszystkie te biblijne sformułowania i wypowiedzi wpłynęły niewątpliwie na późniejsze wykrystalizowanie się wyrażenia i pojęcia „rodzina Kościołem domowym”. To te nawrócone domy (rodziny) były pierwszymi Kościołami, wspólnotami promieniującymi chrześcijaństwem, żyjącymi Chrystusem i ukazującymi Go innym ${ }^{4}$.

Trzeba bowiem pamiętać, że wtedy, na samym początku, życie chrześcijan organizowało się przede wszystkim w Kościele domowym. Nie istniały jeszcze specjalne domy zebrań ani kościoły, toteż w początkach nowo powstałe, zapewne niezbyt liczebne społeczności kościelne, gromadziły się w prywatnych domach (oǐkos, oíkí $\alpha)^{5}$. Wiemy też, jak ważną rolę w rozwijaniu życia religijnego $\mathrm{w}$ czasach przedchrześcijańskich pełnił dom żydowski i rodzina żydowska: do tego wzorca nawiązywały zapewne i Kościoły chrześcijańskie. Sam zresztą Jezus w swej mowie misyjnej polecał, by po wejściu do jakiegoś miasta lub wioski szukać godnego domu i tam - po wyrażeniu życzenia pokoju - rozpoczynać głoszenie słowa Bożego (Łk 10, 5-7). W czasach bowiem starożytnych dom stanowił podstawową komórkę życia wspólnotowego. W odróżnieniu od dzisiejszej rodziny obejmującej tylko rodziców i dzieci, do ówczesnego „domu”, zwłaszcza rzymskiego, zaliczano również dalszych krewnych i niewolników, a nawet klientów, którzy w większych domach mogli stanowić pokaźną grupę ${ }^{6}$. To w takich domach kwitło całe bogac-

${ }^{4}$ F.W. Filson, The significance of the early house churches, JBL 58 (1939) 105-112; K. Gamber, Die frühchristliche Hauskirche nach Didascalia Apostolorum II 57, 1- 58, 6, StPatr 10 (1970) 337344; A. Yarbrough, Christianization in the fourth century: the example of Roman women, ChH 45 (1976) 149-165; H.J. Klauck, Die Hausgemeinde als Lebensform im Urchristentum, MThZ 32 (1981) 1-15; tenże, Hausgemeinde und Hauskirche im frühen Christentum, „Stuttgarter Bibelstudien” 103 (1981) 21-26; H.M.J. Gevaryahu, Privathäuser als Versammlungsstätten von Meister und Jüngern, „Annual of the Swedish Theological Institute” 12 (1983) 5-12; R. Aguivre, La casa como estructura base del cristianismo primitivo: les iglesias domesticas, EE 59 (1984) 27-51; Longosz, Rodzina wczesnochrześcijańska, s. 35.

${ }^{5}$ W Nowym Testamencie, głównie w Ewangeliach i Dziejach Apostolskich termin oǔkos występuje 107 razy, a oi kí 93 razy: oznaczają one dom-rodzinę, por. E. Friedel, Der neutestamentliche Oikos-Begriff in seiner Bedeutung für den Gemeindeaufbau, w: Domine, dirige me in verbo tuo. Festschrift M. Mitzenheim, Berlin 1961, 89-106; P. Weigandt, Zur sogenannten „Oikosformel”, „Novum Testamentum” 6 (1963) 49-74; L. Schenke, Zur sogenannten „Oikosformel” im NT, „Kairos” 13 (1971) 226-243.

${ }^{6}$ Por. A. Strobel, Der Begriff des ,Hauses” im griechischen und Römischen Privatrecht, ZNW 56 (1965) 91-100. 
two życia religijnego: wspólna modlitwa (Dz 12, 12), głoszenie słowa Bożego (Dz 5, 42; 16, 52; 20, 20), agapy i uwielbienie Boga (Dz 2, 46). To w takim domu przyjmowano i goszczono misjonarzy (Dz 16, 15), tutaj udzielano także chrztu i sprawowano Eucharystię, a Kościół lokalny składał się z takich licznych Kościołów domowych. Do Kościoła domowego należeli nie tylko sami członkowie rodziny, lecz również ci wszyscy którzy do niego przystali przez chrzest. W takim Kościele domowym z reguły gospodarz domu (pater familias) przewodniczył zebraniom lub przynajmniej o nich współdecydował, zgromadzeni zaś w nim nie czuli się zagrożeni ze strony sceptycznego i wrogo nastawionego otoczenia, okazując sobie poza tym wzajemne wsparcie i solidarność. Dom chrześcijański stawał się miejscem, w którym mogło się rozwijać samodzielne życie, najważniejszym zaś jego aspektem była braterska atmosfera i wspólnota miłości. W takim domu można było przeżywać Kościół jako braterski związek i duchową rodzinę. Braterskie obcowanie z sobą różnych grup i stanów społecznych, starszych i młodych, niewolników i wolnych, ubogich i bogatych, upokarzanych i uprzywilejowanych, kobiet i mężczyzn, ułatwiało niwelowanie i przezwyciężanie wszelkich kontrastów: bliskość rodziny umożliwiała przeżywanie wiary w konkretnych warunkach życia. Kościół domowy był zdolny do samodzielnego przeżywania wiary, w którym jednostka, w mniejszej grupie, mogła lepiej realizować swe osobiste uzdolnienia. Kościół domowy był też przez to miejscem zdobywania doświadczenia dla wielu przyszłych pretendentów do pełnienia odpowiedzialnych funkcji w większej społeczności kościelnej. Taki dom miał wreszcie duże znaczenie jako miejsce krzewienia wiary i pozyskiwania nowych członków, pełnił funkcję misjonarską ${ }^{7}$. Działalność tego rodzaju domowych Kościołów, które istniały od 2. poł. I do końca III wieku, poświadczają wypowiedzi najstarszych autorów literatury chrześcijańskiej, jak m.in. św. Justyn męczennik († 167), który na pytanie sądzącego go prefekta Rustyka, gdzie mieszka i gdzie gromadzi swoich uczniów, odpowiada, że mieszka w pobliżu łaźni tymiotyńskich w Rzymie i tam tylko w swoim wynajmowanym domu spotyka się ze swymi uczniami ${ }^{8}$; to tam wszyscy - ojciec, syn, sąsiad, mąż, żona lub przyjaciel,

\footnotetext{
${ }^{7}$ Por. J. Gnilka, Pierwsi chrześcijanie: źródła i początki Kościoła, tłum. W. Szymona, Kraków 2004, 420-423 (Kościół domowy); tenże, Haus, Familie und Hausgemeinde, w: Der Philemonbrief. Auslegung J. Gnilka, Herders Theologischer Kommentar zum NT, Bd. X 4, Freiburg 1982, 17-33; P. Lampe, Zur gesellschaftlichen und kirchlichen Funktion der „Familie” in neutestamentlichen Zeit, „Reformatio” 1 (1982) 535-542; W. Vogler, Die Bedeutung der urchristlichen Hausgemeinden für die Ausbreitung des Evangeliums, ThLZ 107 (1982) 785-794; G. Delling, Zur Taufe von „Häusern” im Urchristentum, w: Studien zum NT und zum hellenistischen Judentum. Gesammelte Aufsätze 1950-1968, Göttingen 1970, 288-310; H.J. Klauck, Hausgemeinde und Haustafeln im frühen Christentum, Stuttgart 1981.

${ }^{8}$ Por. Martyrium Justini 5, 1-5, ed. H. Musurillo: The Acts of the Christian Martyrs, Oxford 1972, 44-49, tłum. A. Lisiecki, POK 4, s. XXIII-XXIV: „Prefekt Rustykus rzekł: «Gdzie się odbywają wasze zebrania»? Justyn odpowiedział: «Tam, gdzie każdy chce i może. Czy ty może
} 
czują się bezpieczni, jak bracia ${ }^{9}$. Podobnie wcześniej Eliusz Arystydes z Aten w swojej Apologii, skierowanej najpierw do cesarza Hadriana, a następnie w latach 140-145 do cesarza Antonina Piusa, przedstawiając atrakcyjny obraz życia chrześcijan podkreślał, że wszyscy oni czują się kochającymi braćmi, a gdy spotkają obcego przybysza, chętnie ,wprowadzają go pod swój dach"

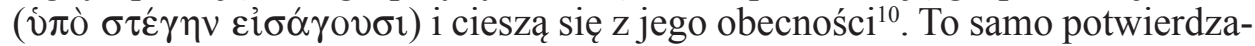
ją oddające najstarszą atmosferę życia chrześcijan Pseudoklementyny stwier-

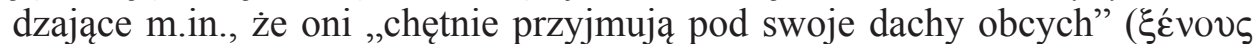

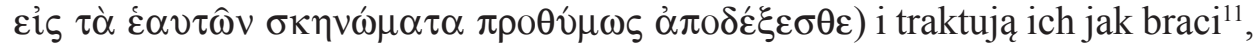
gdy zaś między wierzącymi a niewierzącymi pojawiają się spory, rozwiązują je w domu ${ }^{12}$. Już te kilka przytoczonych wypowiedzi świadczy, że chrześcijański dom był wówczas nie tylko miejscem spotkań i modlitwy, ale pełnił także funkcję apostolską - poprzez przykładne życie swoich członków pozyskiwał zwolenników dla Ewangelii ${ }^{13}$.

Zachowało sie też wiele archeologicznych śladów poświadczających istnienie takich kościołów domowych w epoce przedkonstantyńskiej ${ }^{14}$, jak np. w Syrii - w Dura Europos ${ }^{15}$ na zachodnim brzegu Eufratu z lat 165-265; w Rzymie ${ }^{16}$ - kościół św. Klemensa, kościół św. Jana i Pawła na Monte Celio (dwupiętrowy dom prywatny), kościół św. Sylwestra i św. Marcina ai Monti, kościół św. Pryski na Awentynie, kościół św. Cecylii na Zatybrzu; w północ-

myślisz, że my wszyscy w jednym się zbieramy miejscu? Tak nie jest. Albowiem Bóg chrześcijan nie zajmuje żadnego miejsca; On jest niewidzialny, przepełnia niebo i ziemię, i wierni wszędzie Mu cześć i chwałę oddają». Prefekt Rustykus rzekł: «Powiedz, gdzie się odbywają wasze zebrania, i w którym miejscu zgromadzasz uczniów swoich»? Justyn odpowiedział: «Mieszkam w pobliżu niejakiego Marcina, obok łaźni tymiotyńskich, i to przez cały ten czas, a przebywam w Rzymie obecnie po raz drugi. Żadnego innego miejsca zebrań nie mam, tylko tamto»”.

${ }^{9}$ Por. Justinus, Apologia II 1, 2, SCh 507, 512, thum. L. Misiarczyk, BOK 24, 271.

${ }^{10}$ Por. Aristides, Apologia 15, 6, SCh 470, 288, thum. L. Misiarczyk, BOK 24, 145: ,[...] nie pogardzają wdową, ani też nie uciskają sieroty; zamożny hojnie wspiera ubogiego, a gdy widzą przybysza, wprowadzają go do swego domu i cieszą się z niego, jak z prawdziwego brata. Samych siebie nazywają właśnie braćmi, jednak nie według ciała, lecz według ducha”.

${ }^{11}$ Por. Pseudo-Clementinae hom. 3, 69, 1, GCS 42, 81: „Przyjmujcie serdecznie pod swoje

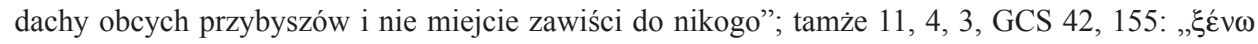

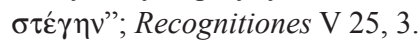

${ }^{12}$ Por. Recognitiones II 29, PG 1, 1265B: „In unaquaque enim domo, cum inter credentem et non credentem coeperit esse diversitas, necessario pugna sit, incredulis quidem contra fidem dimicantibus, fidelibus vero in illis errorem veterem et peccatorum vitia confutantibus".

${ }^{13}$ Przykłady tego zob. A. Harnack, Die Mission und Ausbreitung des Christentums in den ersten drei Jahrhunderten, Leipzig 1924 (Nachdruck 1965), 405-409.

${ }^{14}$ Por. B. Filarska, Początki architektury chrześcijańskiej, Lublin 1983, 23-36 (Domy Kościoła); taż, Archeologia chrześcijańska, Warszawa 1999, 52-60 (Domus Ecclesiae).

${ }_{15}$ Por. A. Gerkan, Zur Hauskirche von Dura Europos, w: Mullus. Festchrift Th. Klauser, Münster 1964, 143-149; C.H. Kraeling, The excavations at Dura Europos. Final Report, Bd. 2: The Christian Building, New Haven 1967.

${ }^{16}$ Por. J.M. Petersen, House-churches in Rome, VigCh 23 (1969) 264-272. 
nej Italii - w Akwilei i Parenzo; w Palestynie - dom św. Piotra w Kafarnaum; w Afryce - w Hipponie, itd. Wzorcami dla nich mogły być domowe synagogi budowane przez Żydów od czasów babilońskich po zniszczeniu Świątyni Jerozolimskiej; to od nich wzięły początek późniejsze tituli ecclesiae.

$\mathrm{Na}$ kształtowanie się autorytetu ojca, który zdaniem Jana Chryzostoma, winien pełnić ważną rolę $\mathrm{w}$ rodzinie chrześcijańskiej (nazywanej kościołem domowym), na wzór biskupa lub kapłana w kościele, mogła też w jakiś sposób wpłynąć wielowiekowa pozycja ojca w rodzinie starożytnej, zwłaszcza rzymskiej, w której pater familias pełnił też m.in. funkcję kapłana ${ }^{17}$. To on w rodzinie rzymskiej z tradycjami, które bez wątpienia oddziaływały na wschodnie części Cesarstwa, odpowiedzialny był za podtrzymywanie w swym domu kultu religijnego, który przejawiał się w formie kultu ogniska domowego i w formie kultu przodków (maiorum). Rodzina bowiem, w której małżonkowie, jak wskazywała definicja małżeństwa, współuczestniczą w prawach boskich i ludzkich ${ }^{18}$, stanowiła swego rodzaju sanktuarium $\mathrm{z}$ własnym ogniskiem domowym, z własnymi tradycjami i zwyczajami, z własnymi rodzinnymi bóstwami (lary i penaty, geniusze, Westa, Junona Lucina, Janus, Liber) i świętami (matronalia, feralia, parilia, liberalia, compitalia), z własnym domowym ołtarzykiem (ara), przed którym często, zwłaszcza w uroczystości rodzinne (urodziny - dies natalis, małżeństwo domownika, pierwociny, pogrzeb), domownicy się zbierali i pod przewodnictwem pater familias według własnego rytu zanosili modły (supplicationes) i składali drobne, przeważnie bezkrwawe (kwiaty: fiołki lub róże, wonne zioła, ciastka, pierwsze krople wina lub pierwociny zbiorów, a w czasie ceremonii małżeństwa - dziecięce zabawki i stroje oraz pukle dziecięcych włosów) ofiary (sacra privata). Ojciec w rodzinie był również odpowiedzialny za kult przodków, który wyrażał sie w trosce o maski zmarłych przodków (przechowywane w atrium-salonie, wynoszone podczas uroczystości rodzinnych - ślubów i pogrzebów) oraz utrwalanie w synach i domownikach ich wybitnych czynów i historii, gdyż wierzono, że zmarli przodkowie przechodzą do rzędu bogów, a jako takim należy się cześć boska i pamięć ${ }^{19}$. Ten obowiązek podtrzymywania kultu rodzinnego przez pater familias uważano za rzecz najcenniejszą, jaką rodzina posiadała, gdyż dzięki niemu utrwalały się $s a c r a^{20}$. O rodzinie $\mathrm{z}$ tak bogatym kultem i tradycjami wyrażał się z zachwytem Cyceron wołając:

${ }^{17}$ Por. m.in. M. Roberti, „Patria potestas” e „paterna pietas”, „Studi Albertoni” 1 (1935) 260270; B. Łapicki, Władza ojcowska w starożytnym Rzymie. Okres klasyczny, Warszawa 1937; B.F. Wierzbowski, Treść władzy ojcowskiej w rzymskim prawie poklasycznym, Torun 1977.

${ }^{18}$ Por. Modestus, Digestae 23, 2, 1: „Nuptiae sunt coniunctio maris et feminae, et consortium omnis vitae, divinae et humani iuris communicatio".

${ }^{19}$ Por. Cicero, De legibus II 22: „Maiores eos, qui ex hac vita migrassent, in deorum numero esse voluissent".

${ }^{20}$ Por. Livius, Ab Urbe condita I 9; S. Longosz, Najstarsze modlitwy rzymskie w przekazie Liwiusza, STar 8 (1981) 53-62. 
„Cóż może być świętszego, cóż bezpieczniejszego od wszelkiej religii, niż dom każdego z obywateli? W nim są ołtarze, w nim ogniska, w nim bogowie rodzinni - penaty; w nim mieszczą się ofiary, w nim zwyczaje religijne i ofiary: w nim jest tak święte i bezpieczne schronienie dla wszystkich, że stąd nie można nikogo wyrwać" 21 .

Choć tego rodzaju kult rodzinny był tak drogi dla społeczeństwa starożytnego, że stanowił jedną z największych przeszkód do przyjmowania chrześcijaństwa w rodzinach i nie mógł na nie bezpośrednio oddziaływać, to jednak sama pozycja ojca rodziny, głównego odpowiedzialnego za praktyki i atmosferę religijną w nim panującą, mogły w jakiś sposób wpływać na kształtowanie się autorytetu ojca w rodzinie chrześcijańskiej jako kościele domowym. Źródła starożytne nie informują nas jednak, żeby ojciec w rodzinie pogańskiej uczył dzieci i domowników o czci bogów, jakichś modlitw, śpiewów i praktyk religijnych, czy też składania ofiar bóstwom domowym - oni uczyli się tego z uczestnictwa w rodzinnych modłach, ofiarach i uroczystościach.

Największy jednak wpływ na ukonstytuowanie się pojęcia „,rodzina kościołem domowym" wywarła rodzina żydowska, zwłaszcza ta żyjąca w diasporze, w otoczeniu często wrogiego sobie środowiska. Ona to stanowiła swego rodzaju zamknięte na wpływy zewnętrzne sanktuarium, zamkniętą domową synagogę, w której ojciec jak kapłan przewodniczył codziennej modlitwie i śpiewowi psalmów swoich domowników, oraz jak nauczyciel i wychowawca uczył ich Tory i prawd religijnych, objaśniał Biblię, przekazywał pierwsze zasady moralne i uporczywie przypominał o najważniejszych wydarzeniach historii Izraela, zwłaszcza o wyjściu z Egiptu ${ }^{22}$. Do tego rodzaju działalności zobowiązywał izraelskich ojców sam Jahwe ${ }^{23}$, taką ich działalność poświadcza wielokrotnie Pismo Święte Starego Testamentu ${ }^{24}$, a czynili to oni regular-

${ }^{21}$ Por. Cicero, Pro domo sua 41, 109: „Quid est sanctius, quid omni religione munitius, quam domus uniuscuiusque civium? Hic arae sunt, hic foci, hic di Penates, hic sacra, religiones, caerimoniae continentur; hoc perfugium est ita sanctum omnibus, ut inde abripi neminem fas sit"; zob. też M. Borda, Lares. La vita familiare romana, Città del Vaticano 1947; D. Wachsmuth, Aspekte des antiken mediterranen Hauskults, „Numen” 27 (1980) 34-75; H. Insadowski, Rzymskie prawo matżeńskie a chrześcijaństwo, Lublin 1935, 77-78; M. Jaczynowska, Religie świata rzymskiego, Warszawa 1987, 23-28 (Bóstwa opiekuńcze domu); G.G. Orr, Roman domestic religion: the evidence of the household shrines, ANRW II 16, 2, 1557-1591.

${ }^{22}$ Por. Pasquato, Eredità giudaica e famiglia cristiana, s. 71-86.

${ }^{23}$ Por. Pwt 6, 6-7: ,Słuchaj, Izraelu [...]. Niech pozostaną w twym sercu te słowa, które ja ci dziś przekazuję. Wpoisz je twoim synom, będziesz o nich mówił przebywając $\mathrm{w}$ domu, w czasie podróży, kładąc się spać i wstając ze snu”; Pwt 11, 18-19: „Weźcie sobie moje słowa do serca i duszy [...]. Nauczcie ich wasze dzieci, powtarzając je im, gdy przebywacie w domu, gdy idziecie drogą, gdy kładziecie się i wstajecie”; Pwt 32, 46: „Weźcie sobie do serca te wszystkie słowa, które ja wam dzisiaj ogłaszam, nakażcie waszym dzieciom pilnie strzec wszystkich słów tego Prawa"; Wj 10, 1-2: „Idź do faraona [...], abyś opowiadał dzieciom twoim i wnukom, co zdziałałem w Egipcie. A znaki moje czyniłem między nimi, aby wiedzieli, że ja jestem Pan".

${ }^{24}$ Por. Ps 44, 2-3: „Boże, słyszeliśmy na własne uszy: ojcowie nasi nam opowiadali o czynach, 
nie podczas obchodów świąt Paschy ${ }^{25}$ i Przaśników ${ }^{26}$. To ojciec winien sobie najpierw przyswoić pewne treści religijne i ważniejsze wydarzenia z historii Izraela prowadzonego przez Jahwe, a następnie przekazywać je regularnie, szczególnie podczas świąt, swoim domownikom, zwłaszcza dzieciom, by je zapamiętały, a nie zaginęły. Pierwszym chrześcijanom, zwłaszcza wywodzącym się z judaizmu, znany był ten rodzinny sposób przeżywania religii, i gdy znaleźli się we wrogim sobie otoczeniu, zaczęli go naśladować w swoich domach, wypełniając go tylko treścią ewangeliczną, kładąc równocześnie podwaliny pod późniejsze Chryzostomowe określenie „rodzina małym kościołem domowym".

\section{RODZINA KOŚCIOŁEM DOMOWYM W ROZUMIENIU JANA CHRYZOSTOMA}

Jan Chryzostom nie jeden tylko raz, ale ponad 10 razy nazwał w swoich pismach rodzinę chrześcijańską, „kościołem domowym” wskazując na wiele aspektów, dzięki którym podobna jest ona, jego zdaniem, do kościoła, zarówno jako domu modlitwy, jak i wspólnoty wierzacych. Nazywanie jakiejś chrześcijańskiej wspólnoty, pogrążonej w modlitwie i żyjącej według zasad Ewangelii, Kościołem, mające swe uzasadnienie w Dziejach Apostolskich i Listach Pawłowych, bliskie było Złotoustemu i często się nim posługiwał ${ }^{27}$, zwłaszcza przy ich komentowaniu, gdy wyrażał swój podziw dla ludzi żyjących w ten sposób:

„«Pozdrówcie [...] Nymfasa i Kościół, który gromadzi się w jego domu» (Kol 4, 15). Widzisz, za jak wielkiego męża go [Nymfasa] uważa, ponieważ jego

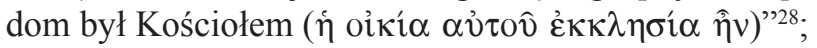

„«Do Filemona [...] i do Kościoła gromadzącego się w tym domu» (Fil 1-2) [...], że był on godnym podziwu wynikało z tego, iż cały jego dom był wie-

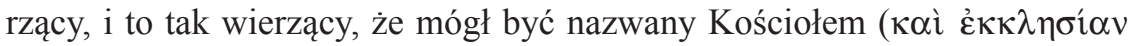

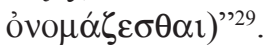

\footnotetext{
których za ich dni dokonałeś, za dni starożytnych”; Pwt 32, 7: „Zapytaj ojca, by ci oznajmił, i twoich starców, niech ci opowiedzą, jak Najwyższy rozgraniczał narody, rozdzielał synów człowieczych i ludom wytyczał granice".

${ }^{25}$ Por. Wj 12, 26-27: „Gdy was zapytają wasze dzieci: co to za święty zwyczaj? - wy im tak odpowiedzcie: To jest ofiara Paschy na cześć Pana, który w Egipcie ominął domy Izraelitów. Poraził Egipcjan, a domy nasze ocalił".

${ }^{26}$ Por. Wj 13, 8: „W tym dniu będziesz opowiadał synowi swemu: Dzieje się tak ze względu na to, co uczynił Pan dla mnie w czasie wyjścia z Egiptu".

${ }^{27}$ Por. L. Brottier, De l'Église hors de l'Église au ciel anticipé sur quelques paradoxes Chrysostomiens, RHPhR 76 (1996) 277-292, spec. 284-288.

${ }^{28}$ In epistulam ad Colossenses hom. 12, 1, PG 62, 381D.

${ }^{29}$ In epistulam ad Philemonem. Introductio, PG 62, 701.
} 
„«Pozdrówcie współpracowników moich [...] Pryskę i Akwilę [...] a także Kościół, który gromadzi się w ich domu» (Rz 16, 3 i 5) [...]. Tak bowiem byli

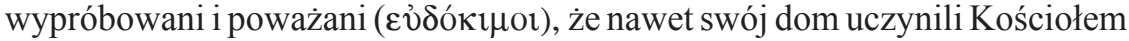
( $(\pi \imath \sigma \tau 0 \grave{\varsigma})$ i otwarli go dla wszystkich przybyszów. Nie ma bowiem zwycza-

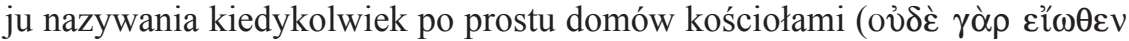

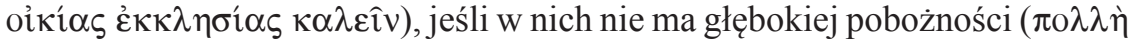

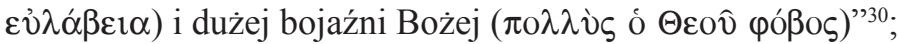

„Nie mała to jest ich [Pryscylli i Akwili - 1Kor 16, 19] zasługa, że nawet swój

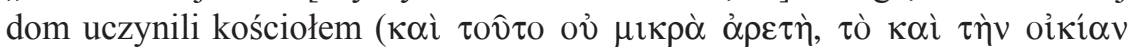

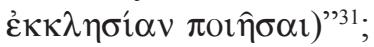

„Kim byli [«Pozdrówcie Pryscyllę i Akwilę» - Rz 16, 3] - wyrabiaczami namiotów w swoim zakładzie. Ani bowiem zawód, ani ubóstwo nie jest przeszkodą, by był szczęśliwy ten, kto porzuciwszy przepych całego miasta, w takiej siedzibie przebywa. Dlaczego i z jakiej przyczyny? Nie żeby ona miała kolumny, nie żeby posiadała obrazy i posadzkę ozdobioną mozaikami, nie żeby miała złoty sufit, nie żeby posiadała tłumy niewolników lub obsługę eunuchów, ale przede wszystkim dlatego, że ich dom był czysty i skromny, że mąż i żona zdobywając utrzymanie z uczciwej pracy uczynili swój

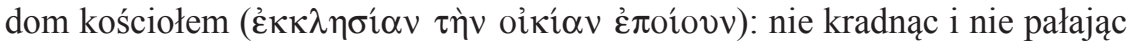
chciwością, lecz wykorzystując uczynki ciała do zdobywania niezbędnego i skromnego utrzymania. Dlatego też przede wszystkim Paweł uznał ten dom za odpowiedni na swe zamieszkanie"32.

Powyższe wypowiedzi przybliżają nam odpowiedź, kiedy, zdaniem Jana Chryzostoma, można dom - rodzinę nazwać Kościołem? - wtedy, kiedy wszyscy domownicy są wierzącymi, kiedy gospodarze nauczają prawd wiary i czynią wszystkich wierzącymi, kiedy dom jest pełen głębokiej pobożności i bojaźni Bożej oraz jest otwarty dla wszystkich przybyszów, kiedy jest czysty i skromny, a jego uczestnicy nie kradnąc i nie pałając chciwością uczciwie zarabiają na swe utrzymanie.

Owszem, według naszego Autora, każde miejsce, na którym odbywa się modlitwa, śpiewanie psalmów, sprawowanie Eucharystii lub przebywają w nim ludzie świeci, może być w przenośni nazwane kościołem: może nim być nawet więzienie, siedziba katów lub rynek miejski:

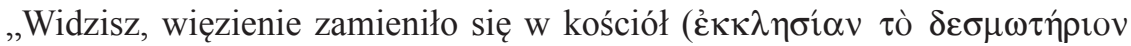

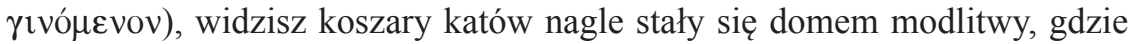
miała być odprawiana święta mystagogia. Jakże wielką rzeczą jest być czuj-

\footnotetext{
${ }^{30}$ In epistulam ad Romanos hom. 30, 3, PG 60, 664.

${ }^{31}$ In epistulam I ad Corinthios hom. 44, 2, PG 61, 376.

${ }^{32}$ Homilia de studio praesentium 4, PG 63, 490.
} 
nym i nie zaniedbywać nigdy duchowych zysków, ale wykorzystywać każdy czas na ich zdobywanie" ${ }^{33}$;

„Kajdany Pawła weszły do więzienia, i cokolwiek tam było, uczyniły kościo-

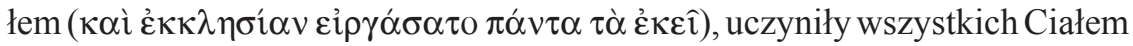

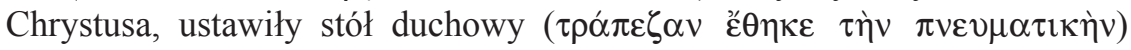
i przygotowały owoce, z których cieszyli się aniołowie"34;

„Wielu było takich, którzy narażając życie odwiedzało ich w więzieniu, ono stało się miejscem śpiewania psalmów, świętych czuwań oraz wielu pełnych pociechy duchowych pouczeń, tak że po zamknięciu kościoła, wiezienie od-

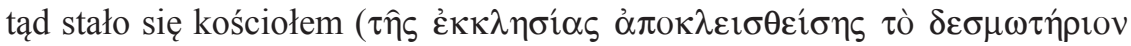

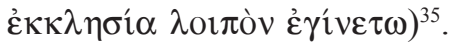

Do zamienienia jakiegoś miejsca w kościół przyczyniają się niekiedy, według naszego Kaznodziei, zaistniałe dramatyczne okoliczności; takimi był m.in. gniew cesarza w 387 r. za zniszczenie jego pomników w mieście, po którym ono samo i jego rynek zamieniły się w jeden kościół, gdy jego mieszkańcy podjęli ekspiacyjną pokutę i błagalną modlitwę, by nie spotkała ich kara:

„Miasto się nam każdego dnia oczyszczało: ulice, dzielnice i rynki stały się wolne od bezwstydnych i rozwiązłych piosenek, i gdziekolwiek byś spojrzał, widziałbyś błagalne modlitwy, błogosławieństwa i łzy, zamiast rozwiązłego śmiechu i brzydkich słów, słowa pełne filozofii - całe miasto stało sie nam ko-

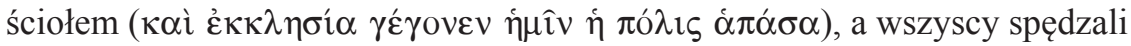
swój czas na publicznych suplikacjach i oddawali swój zapał na wzywanie Boga jednym wspólnym głosem"36.

Taką okolicznością było też trzęsienie ziemi, które wywołało ogromne przerażenie mieszkańców Antiochii, którzy podjęli przebłagalne modły, nocne czuwania i wspólną pokutę, zamieniając całe miasto w kościół:

„Przechodziliście przez rynek, uświęciliście powietrze, które stało sie święte przez śpiewanie psalmów, uświęciliście ziemię, rynek, a miasto uczyniliście

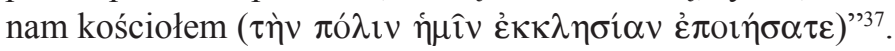

Taką również okolicznością było pierwsze wygnanie Jana z jego biskupiej stolicy Konstantynopola w 403 roku, które wywołało radykalną przemianę u jej mieszkańców, pobudzając ich do pokuty

\footnotetext{
${ }^{33}$ In illud: „Diligentibus Deum” 4, PG 51, 170-171.

${ }^{34}$ In epistulam ad Ephesios hom. 8, 5, PG 62, 62.

${ }^{35}$ In Juventinum et Maximinum martyres 2, PG 50, 575A.

${ }^{36}$ De statuis 15,1, PG 49, 154D-155A.

${ }^{37}$ Homilia post terrae motum, PG 50, 714A.
} 
i modlitwy celem wyproszenia jego powrotu, dzięki czemu miasto zamieniło się w kościół, a on tryumfalnie powrócił:

„Przedtem jedynie kościół się wypełniał, a wtedy i teraz nawet rynek stał sie kościołem" ${ }^{\text {"3 }}$

„Co za nowe i niezwykłe rzeczy! Pasterz nieobecny - trzoda skacze z radości; wódz daleko, a żołnierze się zbroją; już nie tylko Kościół miał wojsko, ale

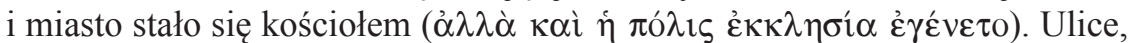
rynki powietrze, wszystko było uświęcane; heretycy się nawracali, Żydzi się poprawiali" ${ }^{39}$.

Elementem jednak, który najbardziej, zdaniem naszego Autora, upodabniał dane miejsce do kościoła, to odprawiana na nim modlitwa, zwłaszcza modlitwa nocna, analogiczna do wigilii nocnych odbywanych w kościele:

„Za dnia nauczanie, w nocy czuwanie; dzień konkuruje z nocą; tam i tu ze-

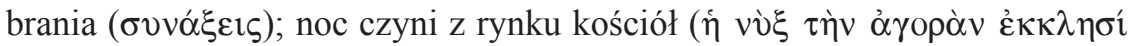
$\alpha v \varepsilon \dot{\varepsilon} \gamma \gamma \alpha \dot{\zeta} \varepsilon \tau \alpha \imath)$; żar waszego ducha gorętszy jest od ognia; nie potrzebujecie zachęty, bo już przez to poświadczacie swoją gorliwość" ${ }^{40}$.

Wszystkie wyżej wskazane przejawy pobożności we wspólnocie chrześcijan - gorąca wiara i gorliwość, życie w bojaźni Bożej, gościnność, przestrzeganie zasad Dekalogu, praktykowanie dobrych uczynków i pielęgnowanie cnót, a przede wszystkim modlitwa, czuwania nocne, śpiewanie psalmów i sprawowanie Eucharystii - składają się, zdaniem Jana Chryzostoma, na to, że dana wspólnota lub miejsce podobne są do kościoła, a nawet można je nazwać kościołem.

$\mathrm{Na}$ tym tle warto teraz wyszczególnić te aspekty, które zdaniem naszego Złotoustego, upodabniały rodzinę chrześcijańską do kościoła, tym bardziej, że wielu późniejszych autorów, zwłaszcza nowożytnych, posługujących się tym wczesnochrześcijańskim określeniem, wskazywać będzie również na inne aspekty, które w dzisiejszych okolicznościach upodabniają te dwie instytucje do siebie.

${ }^{38}$ Sermo post reditum a priore exilio 1, 1, ed. B. de Monfaucon, III, Paris 1721, 424; zob. In illud: „Ne timueris” 1, 2, PG 55, 501-502: „Nie na cały dzień, ale na chwilę wstąp do kościoła [...],

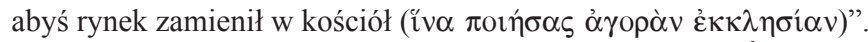

${ }^{39}$ Tamże, Sermo 2, 2, PG 52, 44A, tłum. T. Sinko: Św. Jan Złotousty, Dwadzieścia homilij i mów, Kraków 1947, 273; zob. tamże, PG 52, 445A, Sinko, s. 275: „Przez jednego człowieka morze stało się miastem. Były tam kobiety, mężczyźni i dzieci nieletnie. Kobiety niosły dzieci i śmiało powierzały się morzu, lekceważyły fale. Niewolnik nie bał się pana, niewiasta nie pamiętała o swej słabości cielesnej, rynek zamienił się w kościół (

${ }^{40}$ Homilia de Chananea 1 , PG 52, 449A. 
1. Ojciec, jak biskup w kościele, jest odpowiedzialnym nauczycielem prawd wiary w rodzinie. Jest to najczęściej wskazywane przez Jana Chryzostoma podobieństwo między rodziną chrześcijańską a kościołem. Oprócz wielowiekowej klasyczno-judaistycznej tradycji, według której ojciec jako głowa rodziny był również w swoim domu nauczycielem i stróżem tradycji rodzinnych i religijnych, na Jana Chryzostoma wpłynęła w tym wypadku wypowiedź św. Pawła (1Tm 5, 4-5), że nie może należycie kierować Kościołem ten, kto nie potrafi dobrze zarządzać swoim domem:

„Pouczaj swą żonę, a w ten sposób będziesz zarząazzać domem. Słuchaj, co mówi Paweł: «A jeśli [kobiety] chcą się czegoś nauczyć, niech zapytają w domu swoich mężów» (1Kor 14, 35). Jeśli w ten sposób będziemy rozporządzać swoim domem, staniemy się również godni przewodzenia

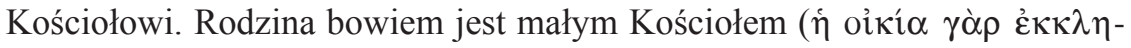

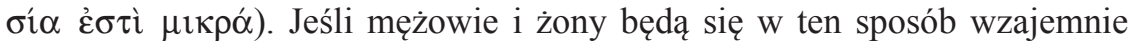
uświęcać, wszystkich przewyższą świętością"41.

Podobnie jak biskup w Kościele poucza swoich wiernych i zarządza nimi, tak i mąż lub ojciec jako głowa rodziny ma obowiązek w domu katechizować i pouczać swoich domowników, odpowiadać na ich pytania i umiejętnie nimi kierować nie tylko w sprawach doczesnych, ale i w drodze do świętości, odpowiednio do zdania św. Pawła: „Dobrze rządzący własnym domem, trzymający dzieci w uległości z całą godnością. Jeśli ktoś nie potrafi zarządzać własnym domem, jakże będzie się troszczył o Kościół Boży” (1Tm 3, 5):

„To twierdzą i pogańscy pisarze, że kto dobrze rządzi we własnym domu, wnet może rządzić także państwem. Albowiem Kościół jest jakoby wielki dom. I jak w domu są synowie, żona, słudzy, a mąż ma władzę nad wszystkimi, tak i w Kościele nie ma nic innego, jak to samo: synowie, niewiasty, słudzy. A jeśli przełożony Kościoła ma wspólników rządu, to także w domu mąż ma za wspólniczkę żonę [...]. Ma i w domu mąż niewolników i córki. Zresztą nawet łatwiej jest rządzić domem. A kto nim dobrze nie zarządzał, jak będzie mógł rządzić Kościołem?" ${ }^{2}$.

Chryzostom rozwija tu myśl św. Pawła, że nie może dobrze zarządzać wspólnotą kościelną ten, kto nie potrafi umiejętnie rządzić własną rodziną. Eksponuje tu rolę ojca, który podobnie jak w tradycji żydowskiej, jest przede wszystkim odpowiedzialny za religijno-moralne wychowanie dzieci i domowników ${ }^{43}$.

${ }^{41}$ In epistulam ad Ephesios hom. 20, 6, PG 62, 143, thum. M. Jurek, BOK 19, 60; zob. Longosz, Rodzina wczesnochrześcijańska kościołem domowym, s. 36nn.

${ }^{42}$ In epistulam I ad Timotheum hom. 10, 2, PG 62, 549, thum. T. Sinko: Św. Jan Złotousty, Homilie na listy pasterskie św. Pawła i na List do Filemona, Kraków 1949, 105.

${ }^{43}$ Por. D. O'Roark, Parenthood in late antiquity: the evidence of Chrysostom, GRBS 40 (1999) 53-81; A. Uciecha, Rola ojca w procesie wychowania domowego na podstawie traktatu św. Jana Chryzostoma „O wychowaniu dzieci”, w: Dziecko w rodzinie i spoteczeństwie, dz. cyt., ss. 205- 
Ułatwia mu to niewątpliwie władza głowy rodziny nad żoną, dziećmi i służbą: „Jeśli mąż będzie godny szacunku, a głowa piękna, wtedy i reszta ciała nie będzie doznawać żadnego uszczerbku" ${ }^{4}$. To ojcu rodziny przypisuje najwyższą władzę nauczycielską nad domownikami:

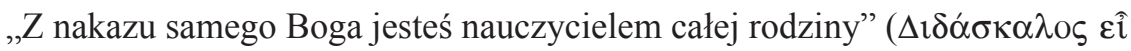

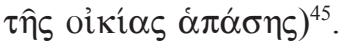

Jako taki zaś, podobnie jak biskup, powinien świecić przykładem wzorowego życia i mądrości, być łagodny i wyrozumiały oraz gorliwy w studiowaniu Pisma Świętego ${ }^{46}$.

W związku z powyższym Jan zachęca wielokrotnie ojców, by po powrocie z kościoła do domu powtarzali swoim domownikom - żonie, dzieciom i służbie, treść wysłuchanego tam kazania, by obok materialnego stołu z pokarmami zastawiali im również stół słowa Bożego: wtedy dom stanie się prawdziwie kościołem, w którym działa Duch Święty rozsiewając pokój i zgodę; powtórzenie domownikom wysłuchanego w kościele słowa Bożego jest przedłużeniem $\mathrm{w}$ rodzinie kościoła i jego atmosfery:

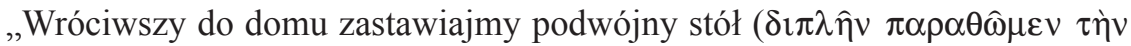
$\tau \rho \alpha ́ \pi \varepsilon \zeta \alpha v)$ : jeden z pokarmami, a drugi ze świętymi czytaniami; mąż niech powtórzy to, co tam zostało powiedziane, niech się tego nauczy żona, niech posłuchają dzieci, niech tego czytania nie będą pozbawieni i inni domow-

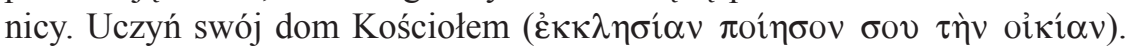
Odpowiadasz za zbawienie dzieci i domowników, i jak my odpowiadamy za was, tak też każdy z was odpowie za domowników - za żonę i za dzieci” ${ }^{47}$.

218; O. Pasquato, Pastorale familiare. La testimonianza di Giovanni Crisostomo, „Salesianum”51 (1989) 15-16.

${ }^{44}$ In epistulam ad Ephesios hom. 20, 6, PG 62, 143, BOK 19, 60.

${ }^{45}$ In illud ,Vidua eligatur" 9, PG 51, 321.

${ }^{46}$ Por. In epistulam I ad Timotheum hom. 13, 1, PG 62, 565; 17, 1, PG 62, 591.

${ }^{47}$ In Genesim sermo 6, 2, PG 54, 607C lub SCh 433, 294, thum. S. Kaczmarek, ŹMT 45, 95; por. In Genesim hom. 2, 4, PG 53, 31B: „Niech mąż opowie coś z tych rzeczy, które tu zostały powiedziane; niech posłucha żona, niech uczą się dzieci i domownicy, a dom niech staje się Kościołem

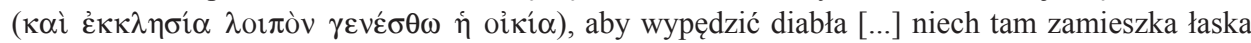
Ducha Świętego, a pełny pokój i zgoda niech ogarną mieszkańców”; In Genesim sermo 8, 2, PG 54, 619-620 lub SCh 433, 360-362, ŹMT 45, 112-113: „Pouczcie też tych, którzy tego nie słyszeli. Zarówno w kościele, jak i na rynku i w domu niech się każdy w tym ćwiczy. Nie ma nic słodszego od pochodzącego od Boga wykładu [...]. Wieczorem podaj ten plaster miodu na stół, aby napełnił wszystko duchową przyjemnością Czy nie widzicie, jak bogaci ludzie po posiłkach wprowadzają śpiewających przy wtórze kitary oraz fletnistów? Oni czynią swe domy teatrem, ty natomiast uczyń swój dom niebem. Uczynisz to nie przez zmienianie murów czy naruszanie fundamentów, lecz przez zaproszenie do twego stołu Pana niebios. Bóg nie powstydzi się takiego posiłku. Tam, gdzie jest nauczanie duchowe i umiar, i powaga, i łagodność; tam gdzie są mąż i żona oraz dzieci, gdzie zgoda i przyjaźń, i gdzie cnota stanowi więź pomiędzy ludźmi - tam pośrodku jest Chrystus. Nie szuka On złotego dachu ani kolumn jaśniejących niczym błyskawice, ani piękna marmurów. Szuka 
„Zachęcałem was wczoraj, abyście pamiętali o tym, co zostało powiedziane, i wieczór zastawili podwójny stół - jeden z pokarmami i drugi dołączony do niego z naukami. Czy uczyniliście to i zastawiliście podwójny stół? [...]. Gdym to wczoraj mówił, aby każdy z was uczynił swój dom Kościołem (ő $\tau$

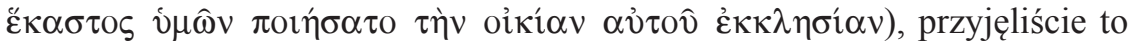
$\mathrm{z}$ wielkim aplauzem" ${ }^{48}$

Ojciec jako głowa rodziny winien więc przenosić z kościoła do swoich domowników jego atmosferę, zasłyszane tam upomnienia i pouczenia religijne, powtarzać je, objaśniać i utrwalać w ich umysłach ${ }^{49}$, stawać się niejako ich domowym duszpasterzem, odpowiedzialnym za ich zbawienie, podobnie jak biskup za zbawienie powierzonej sobie wspólnoty. Jan Chryzostom posługuje się tu, jak widać, stosowaną często w literaturze starożytnej plastyczną metaforą stołu lub biesiady duchowej czy literackiej, bliską platońskiemu obrazowi „,biesia-

natomiast wdzięku duszy i pięknego kształtu sumienia, stołu zastawionego sprawiedliwością, mającego też owoce jałmużny. Gdy zobaczy taki stół, szybko przyłącza się do zgromadzonych i przebywa z nimi [...] Kiedy zatem usłyszawszy, jak ubogi głośno krzyczy na zewnątrz, zaraz dałeś coś ze stołu potrzebującemu, wówczas za pośrednictwem sługi zaprosiłeś do stołu Pana. Napełniłeś stół błogosławieństwami”; In Joannem hom. 3, 1, PG 59, 37: „Trzeba wam o tym mówić i przypominać, abyście w tym duchu postępowali, i nie tylko tu w kościele słuchali, ale i w domu niech o tych rzeczach mąż mówi do żony, ojciec do dziecka: niech każdy mówi swoje i od drugich również wymaga, aby wszyscy na ten temat wzajemnie się wypowiadali. Niech nikt nie mówi, że rodzice nie powinni tymi rzeczami zajmować dzieci: nie tylko powinni, ale ma to być ich jedyna troska"; In epistulam ad Ephesios hom. 20, 9, PG 62, 147, BOK 19, 67: „Módlcie się wspólnie, razem chodźcie do kościoła, a w domu rozmawiajcie o tym, co tam było czytane i mówione"; Ad Antiochenos hom. 6, 7, PG 49, 90: „Wróciwszy do domu, opowiedz to wszystkim domownikom; i jak często wielu wracając z łąki przynosi do stołu róże, fiołki lub jakieś inne kwiaty [...] tak i ty wracając stąd, zanieś to upomnienie dzieciom, żonie i całej służbie. To bowiem upomnienie jest ważniejsze od łąki i stołu”.

${ }^{48}$ In Genesim sermo 7, 1, PG 54, 608A lub SCh 433, 300, ŹMT 45, 96: „Gorąco zachęcałem wczoraj, żeby wasza miłość zapamiętała to, co zostało powiedziane, i żeby wieczorem zastawiła dwa stoły, dodając do stołu pełnego pokarmów ucztę ze słów. I co? Czy to uczyniliście i zastawiliście dwa stoły? Wiem, że to uczyniliście i że spożywaliście nie tylko z pierwszego, ale i z drugiego. Zatroszczywszy się bowiem o pośledniejszy, nie zamierzaliście zaniedbać lepszego. Bo też jest on od tego pierwszego lepszy. Pierwszy stół napełniły ręce kucharzy, drugi zaopatrzyła mowa proroków. Pierwszy ofiarowuje płody ziemi, a drugi - owoc pochodzący z Ducha. Udziałem pokarmów z pierwszego stołu staje się wkrótce zniszczenie, a z drugiego - niezniszczalność. Jeden umacnia nasze doczesne życie, drugi zaś wiedzie nas do przyszłego. Wiem, że zastawiliście jeden i drugi. Nie dowiadywałem się o to u waszego towarzysza ani sługi, lecz u pewniejszego od nich posłańca. U kogo mianowicie? Było to oklaskiwanie wypowiedzianych przeze mnie słów, pochwała nauczania. Bo kiedy wczoraj powiedziałem: «Niech każdy z was uczyni dom kościołem», wznieśliście głośne okrzyki, okazując zadowolenie z tego, co powiedziano"; zob. też De mutatione nominum 1, 2, PG 51, 116-117..

${ }^{49}$ Por. B. Fischer, L'entretien familial prolongement de la prédication, w: Parole de Dieu et sacerdoce, ed. L. Bouyer, Tournai - Roma - New York 1962, 237-255; W. Kania, Pierwsza katecheza domowa w ujęciu św. Jana Chryzostoma, VoxP 5 (1985) z. 8-9, 215-222. 


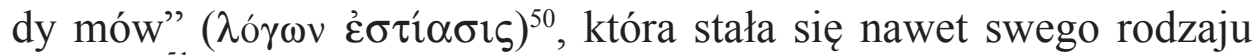
toposem $^{51}$.

Słowo Boże wysłuchane w kościele winno być starannie zapamiętane, by donieść je w całości do rodziny, gdzie żona i dzieci z należną uwagą wysłuchają je od ojca oraz będą je rozważać i omawiać. On zaś po wysłuchaniu kazania i wyjściu z kościoła winien spieszyć zaraz do domu, nie zatrzymywać się po drodze z przyjaciółmi i niczym nie rozpraszać, by niczego nie uronić:

„Wyszedłszy z kościoła nie wracajmy zaraz do krzykliwych spotkań, bezdusznych rozmów i bezużytecznych zajęć, ale zatrzymując w pamięci to, co tam zostało powiedziane, spieszmy do domu i siedząc z żoną i dziećmi, niech każdy starannie rozważa, co usłyszał [...], abyście nie zmarnowali tego, co usłyszeliście na kazaniu. Przykazania Boże są lampą: «bo lampą jest przykazanie, a światłem Prawo, droga do życia - upomnienie i nagana» (Prz 6, 23). Kto zaś zapala pochodnię, nie przesiaduje na rynku, ale spieszy do domu, aby podmuch wiatrów nie zgasił płomienia, a zbyt długa zwłoka nie wyczerpała ognia. Tak i my czyńmy. Duch Święty rozpalił nas w kościele swoją nauką. Po wysłuchaniu kazania i wyjściu z kościoła spieszmy więc do domu, by w rodzinie, jakby na świeczniku, rozpalić to światło" 52 .

Ważną częścią liturgii kościelnej jest czytanie i objaśnianie Pisma Świętego. Jan Chryzostom wielokrotnie zachęcał, by jak w kościele, czytano również i medytowano Pismo Święte w domu, by w każdym czasie, także przed i po posiłku, brano do rąk boskie księgi ( $\tau \alpha$ $\theta \varepsilon \hat{\imath} \alpha \operatorname{Br} \beta \lambda i ́ \alpha$ ), by na podobieństwo stołu materialnego z pokarmami, zastawiano w nim również, jak wspominaliśmy wyżej - stół duchowy z lekturą i rozważaniem Biblii, z którego domownicy

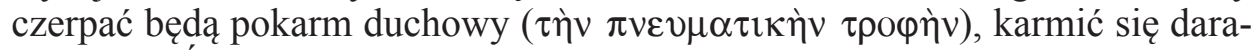
mi Ducha Świętego, umacniać nimi swe umysły i oddalać od siebie zasadzki diabła. Główną rolę w tej dydaktyczno-liturgicznej działalności winien pełnić ojciec rodziny:

„Niech każdy weźmie do rąk boską księgę i zwoławszy najbliższych niech zasila przez boskie wypowiedzi umysł swój i obecnych; abyśmy w ten sposób mogli uniknąć diabelskich zasadzek, zbierać wielkie owoce postu, korzystać z Bożej łaskawości, łaski i miłosierdzia jedynego Jego Syna [...]”,53. „Będziemy słusznie postępować, jeśli przebywając w domu przed i po posiłku brać będziemy do rąk boskie księgi, a przez to czerpać i dostarczać duszy duchowego posiłku. Jak bowiem ciało potrzebuje materialnego pokarmu, tak i dusza codziennego upominania i podawania duchowych pokarmów"s4.

\footnotetext{
${ }^{50}$ Por. Plato, Timaeus 27b.

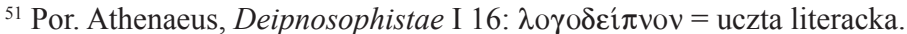

${ }_{52}^{5}$ Sermo de sanctis martyribus 4, PG 50, 651-652.

${ }^{53}$ In Genesim hom. 6, 6, PG 53, 61.

${ }^{54}$ Tamże, 10, 8, PG 53, 90.
} 
Lektura i rozważanie Biblii winny zajmować, zdaniem Złotoustego, w życiu rodzinnym centralne miejsce, i nie można się zadowalać jedynie cotygodniowym dwugodzinnym jej wysłuchiwaniem ${ }^{55}$. Przez tego rodzaju domową lekturę opowiadań o różnych postaciach biblijnych, niejako z nimi obcujemy, zapraszamy je do swojej rodziny oraz gościmy w domu proroków i apostołów, a nawet samego Pana, którzy przez to sami do nas przemawiają, a swój

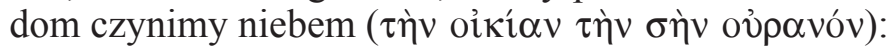

„Cóż mogę począć ja, powiesz, skoro nie ma u mnie Pawła? Jeśli tylko zechcesz, możesz go mieć w sposób jeszcze bardziej skuteczny, niż oni. Przecież ich takimi uczynił nie widok Pawła, lecz słowa Pawła. Tak więc, jeżeli zapragniesz, możesz nieustannie przebywać zarówno z Pawłem, jak i z Piotrem, i z Janem, i z całym chórem proroków i apostołów. Weź księgi tychże błogosławionych mężów i ustawicznie obcuj z ich pismami, a one potrafią uczynić cię takim, jaka była żona wyrabiacza namiotów. Dlaczego mówię o Pawle? Jeżeli zechcesz, możesz gościć u siebie jego Pana, gdyż przez usta Pawła On sam będzie przemawiał do ciebie. I jeszcze inaczej możesz Go ugościć, przyjmując Jego świętych, otaczając troską tych, którzy w Niego wierzą $[\ldots]^{56}$.

„Oni będą z tobą obcować z zaufaniem i z większą swobodą, a dom twój

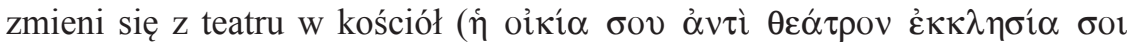
$\gamma \varepsilon v \eta ́ \sigma \varepsilon \tau \alpha \imath)$ diabeł ucieknie, a wejdzie Chrystus z chórem aniołów. Gdzie bowiem jest Chrystus, tam i aniołowie, gdzie zaś Chrystus i aniołowie, tam jest niebo i światło jaśniejsze od promieni słońca" ${ }^{57}$.

Biskup Konstantynopola zaleca domową lekturę Biblii nie tylko dorosłym, ale i dzieciom. W swoim pedagogicznym traktacie $O$ wychowaniu dzieci nauczanie Pisma Świetego uważa za podstawę wychowania religijnego. Proponuje nawet konkretne katechezy biblijne: zamiast mitologicznych bajek wybieranie ciekawych, odpowiednich dla dzieci opowiadań biblijnych (np. o Kainie i Ablu, o Jakubie i Ezawie), przekazanie ich prostym zrozumiałym ję-

${ }^{55}$ Por. In inscriptionem Actorum Apostolorum hom. 3, 2, PG 51, 90: „Zwróćmy zatem uwagę na czytanie, nie tylko te dwie godziny, ale ciągłe; każdy wróciwszy do domu niech bierze do rąk Pismo Święte i śledzi znaczenie tego, co w nim powiedziano oraz pragnie czerpać z niego ciągły i dostateczny pożytek”; In Genesim hom. 29, 2, PG 53, 262: „Proszę was, abyście tu często przychodzili i słuchali uważnie czytań Pisma Świetego; ale nie tylko tu, gdy przychodzicie, także w domu bierzcie do rąk boskie księgi i z wielką starannością czerpcie pożytek w nich zawarty. Z nich bowiem wiele korzyści się rodzi: najpierw poprzez czytanie poprawia się język, a następnie dusza jest ożywiana, usubtelniana i oświetlana promieniami Słońca sprawiedliwości, a przez ten czas uwalniana od nieczystych zasadzek myślowych i napełniana wielkim pokojem"; por. In Joannem hom. 58, 4, PG 59, 319-320.

${ }^{56}$ In epistulam ad Romanos hom. 30, 4, PG 60, 665-666, tłum. T. Sinko: Św. Jan Chryzostom, Homilie na List do Rzymian 1, 2, Kraków 1998, 445; por. In Genesim sermo 8, 2, PG 54, 619-620, zob. wyżej nota 47.

${ }^{57}$ In Matthaeum hom. 48, 7, PG 58, 495, thum. A. Baron - J. Krystyniacki: Św. Jan Chryzostom, Homilie na Ewangelię wedlug św. Mateusza, II, ŹMT 23, Kraków 2001, 88. 
zykiem, utrwalanie ich w pamięci, a później weryfikowanie podczas publicznych nabożeństw w kościele ${ }^{58}$.

Jan Chryzostom, jako jeden z nielicznych Ojców Kościoła, zachęcał swoich wiernych, by na wzór tworzonych przy kościołach podręcznych zbiorów biblijno-liturgicznych książek, nabywali książki religijne i tworzyli z nich biblioteki domowe, w których naczelne miejsce winno zajmować Pismo Święte. To w nim winni szukać lekarstwa na różne zmartwienia i kłopoty domowe, posuwając się nawet do stwierdzenia, że przyczyną wszelkiego zła jest nieznajomość Biblii ${ }^{59}$. Domowa lektura tych książek nie tylko poszerza ich ogólną kulturę religijną, ale i ułatwia zrozumienie liturgicznych czytań w kościele, do czego zachęca wiernych przed wyjściem na liturgię ${ }^{60}$, jakkolwiek uważa, że najlepszym przygotowaniem do ich zrozumienia jest wzorowe życie chrześcijańskie ${ }^{61}$. Ubolewa przy tym, nad duchowym lenistwem swoich wiernych, na brak znajomości u nich podstawowych wydarzeń biblijnych i prawd religijnych, że dobrze znają nazwiska tancerzy, aktorów lub zwycięskich koni wyścigowych, a także wiele świeckich, a nawet obscenicznych piosenek, a nie znają imion proroków, apostołów, ewangelistów, tytułów i liczby ksiąg biblijnych czy wydarzeń w nich opisanych, nie znają również na pamięć żadnego

${ }^{58}$ Por. De inani gloria et liberis educandis 39-46, SCh 188, 130-144, thum. W. Kania, BOK 19, 86-90: „Niech dziecko nie słyszy takich bajek. A gdy się zmęczy nauką - opowiedz mu coś z historii świętej [...] wychowujesz przecież filozofa i obywatela nieba. Opowiedz mu zaś w ten sposób [...]. Przedstaw mu to w jeden wieczór przy stole. Innym razem może mu to uczynić matka. Jeśli już więcej razy słyszało, zapytaj je: «Opowiedz mi tę historię». Niech sobie poczytuje za zaszczyt, że może opowiedzieć [...]. Ale nie przestań na tym, lecz zaprowadź dziecko do kościoła, zwłaszcza po przeczytaniu tego opowiadania. Zobaczysz, jak będzie się cieszyć i radować, iż już zna to opowiadanie"; zob. W. Kania, Pierwsza katecheza domowa w ujęciu św. Jana Chryzostoma, VoxP 5 (1985) z. 8-9, 215-222.

${ }^{59}$ Por. In epistulam ad Colossenses hom. 9, 1, PG 62, 361-362: „Nabywajcie książki jako lekarstwa dla duszy. Jeśli nie chcecie żadnej innej, to zdobądźcie sobie Nowy Testament: Dzieje Apostolskie i Ewangelie jako stałych nauczycieli. Jeśli dosięgnie cię cierpienie, szukaj w tej aptece lekarstwa na chorobę; jeśli spotka cię nieszczęście, śmierć lub strata twoich domowników, znieś to wszystko i zachowaj w duchu. Nieznajomość Pisma Świętego jest przyczyną wszelkiego zła”.

${ }^{60}$ Por. In Matthaeum hom. 1, 6, PG 57, 21, thum. J. Krystyniacki, ŹMT 18, 24: „Aby zaś te pouczenia były bardziej przystępne, prosimy was i błagamy (jak to czyniliśmy przy innych księgach) o wcześniejsze przeczytanie fragmentu Pisma, który mamy objaśniać. W ten sposób czytanie będzie poprzedzało rozumienie, podobnie jak to miało miejsce w przypadku eunucha Etiopa (Dz 8, 27-40), a i nam to rzecz bardzo ułatwi”; In Joannem hom. 11, 1, PG 59, 77: „Mam do was prośbę [...], czego zaś od was żądam? Abyście w jedną z sobót ową perykopę Ewangelii, która podczas kazania będzie czytana, każdy z was wziąwszy do rąk w domu wszyscy często wcześniej czytali oraz jej słowa badali i analizowali, co jest jasne lub niejasne notowali, co w słowach wydaje się być sprzeczne lub niejasne, i tak przygotowani na kazanie przychodzili”; tamże, hom. 58, 4, PG 59, 319-320: „Wielu jest jednak i tak niedbałych, że mimo wysłuchania tylu czytań w kościele, nie znają nawet nazwy księgi, i mają czelność bez jakiegokolwiek przygotowania uczestniczyć w Bożych czytaniach”.

${ }^{61}$ Por. In epistulam ad Ephesios hom. 24, 1, PG 62, 168: „Przygotowaniem zaś do zrozumienia Ewangelii nie jest nic innego, jak bardzo dobre życie". 
psalmu lub fragmentu Pisma Świętego, tłumacząc się brakiem czasu lub że jest to zajęcie dla mnichów ${ }^{62}$. Zdarza się także, iż w swoich domach posiadają różnego rodzaju gry lub zabawy, ale nie mają żadnej książki religijnej, a jeśli je nawet posiadają, to ich w ogóle nie czytają, lecz chełpią się tylko wobec innych ich pięknem lub wartością pergaminów, co prowadzi do ich pełnej ignorancji religijnej:

„Wstydźmy się, że kobieta samarytańska, która miała aż pięciu mężów, dokładała tylu starań, by zdobywać wiedzę, i nie odwodziła jej od tego ani godzina dnia ani żaden inny obowiązek lub zajęcie (J 4, 7-42). My zaś często nie tylko nie pytamy o prawdy wiary, lecz we wszystkim w ogóle jesteśmy gnuśni i opieszali. Któż z was, pytam, sięga w domu po książkę chrześcijańską, bada jej treść, czy też rozważa Pismo święte? - Chyba nikt. U wielu znajdujemy szachy lub kości do gry, ale nigdy książek, albo tylko u nielicznych, którzy często nie lepiej je traktują niż ci, którzy w ogóle ich nie mają, bo trzymają je związane lub zamknięte w szafach, i całą swą uwagę skupiają na delikatności ich pergaminów lub na pięknie ich liter, zaniedbując całkowicie ich czytanie. Nie czerpią z nich żadnego pożytku, ale tylko swe bogactwo i przepych - wyraz próżnej chwały. Nie słyszę, by ktoś chciał posiadać książki, aby poznawać ich treść, ale raczej by się chełpić, iż ma książki złotymi literami pisane. I jakaż, pytam was, płynie z nich korzyść? Nie po to bowiem dano nam Pismo Święte, abyśmy je mieli zapisane tylko w księgach, ale byśmy je wdrażali w nasze serca. $Z$ pewnością takie posiadanie książek jest ambicją żydowską, by przykazania mieć tylko na piśmie. Prawo bowiem na początku nie tak zostało nam dane, ale wypisane na cielesnych tablicach naszego serca. Mówię to nie dlatego, żeby wam zabraniać kupowania książek, owszem, pochwalam to i życzę, by się tak działo, ale chciałbym, żeby i litery i sens Pisma Świętego

${ }^{62}$ Por. In Matthaeum hom. 2, 5, PG 57, 30, thum. J. Krystyniacki, ŹMT 18, 36-37: „Któż z was tutaj stojących potrafiłby, gdyby od niego żądano, powiedzieć z pamięci choć jeden psalm albo jakąś inną część Pisma Świętego? Nie ma nikogo takiego. Jednakże nie tylko to jest smutne, [lecz także to], że będąc aż tak niedbałymi w sprawach duchowych, do szatańskich jesteście bardziej napaleni niż ogień. Przecież, gdyby ktoś pytał was o szatańskie przyśpiewki, o nieprzyzwoite i lubieżne piosenki, znalazłby wielu obeznanych w nich dokładnie i wygłaszających je z wielką przyjemnością. A jaka jest obrona przeciw tym zarzutom? «Nie jestem mnichem, powiadasz, ale mam żonę i dzieci oraz staram się o dom». To właśnie niszczy wszystko, że mniemacie, iż jedynie mnichom przystoi czytanie Pisma Świętego, podczas gdy w rzeczywistości wy potrzebujecie tego o wiele bardziej aniżeli oni. Lekarstwa potrzebują przede wszystkim ci, którzy żyją w świecie i każdego dnia otrzymują rany. Dlatego rzeczą daleko gorszą od nieczytania [Pisma] w ogóle, jest uważanie tego zajęcia za zbyteczne, gdyż takie słowa są szatańskim wymysłem"; In epistulam ad Romanos hom. 1, 1, PG 60, 391, tłum. T. Sinko: Homilie na List św. Pawła do Rzymian, I 1, Kraków 1995, 35: „Boleję nad tym i dręczę się, że nie wszyscy go [Pawła] znają, jak go znać należy, a niektórzy do tego stopnia go nie znają, iż nawet nie wiedzą dokładnie, ile jest jego listów. Nie pochodzi to z braku wykształcenia, lecz z braku chęci do ciągłego obcowania z tym błogosławiony mężem"; In inscriptionem Actorum Apostolorum hom. 1, 3, PG 51, 71: „Dla wielu z pewnością ta księga jest nieznana”; In illud: , Vidi Dominum" 1, 5, PG 56, 104. 
były wyryte w naszej duszy tak, żeby ona po ich przyjęciu się oczyszczała. Jeśli bowiem do domu, gdzie jest Ewangelia, diabeł nie ma odwagi przystąpić, to tym mniej demon lub grzech do duszy nasyconej treściami ewangelicznymi. Uświęcaj więc swoją dusze, uświęcaj swoje ciało oraz miej zawsze te treści w sercu i na języku. Jeśli bowiem nieprzyzwoite słowa plamią dusze i przywołują demony, to jest oczywiste, że lektura duchowa ( $\dot{\eta} \pi v \varepsilon v \mu \alpha \tau \imath \kappa \grave{\eta}$

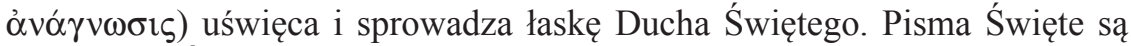
kantykami. Śpiewajmy je więc w duchu i używajmy ich jako lekarstwa na choroby duszy. Gdybyśmy rozumieli to, co jest czytane, to z pewnością słuchalibyśmy tego z większą uwagą. Powtarzam to zawsze bez końca: czyż nie jest absurdem, że ludzie siedzący na rynku znają nazwiska woźniców i tancerzy, ich pochodzenie, miasta i talent, owszem przymioty i wady koni, a kiedy tu przychodzą, nie rozumieją tego, co się tu dzieje, owszem, nawet liczby świętych ksiąg nie znają" ${ }^{63}$.

Już w przedstawionym wyżej obrazie rodziny wczesnochrześcijańskiej jako kościoła domowego łatwo dostrzec pewne analogie i podobieństwa do odwiecznych zwyczajów rodziny żydowskiej, w której również czytywano w domu i omawiano Biblię (także przed i po jedzeniu), a ojciec był wychowawcą i nauczycielem swoich domowników, odpowiadał na religijne pytania dzieci (Pwt 6, 4-5; 11, 8; 32, 46; Wj 12, 26; 13, 8), przekazywał treści zasłyszane w synagodze, i jak w judaizmie był przedłużeniem nauczyciela synagogi, tak tu był przedłużeniem biskupa lub kapłana, komentującego Biblię w kościele. W swoim nauczaniu o rodzinie chrześcijańskiej Jan Chryzostom przejął niemało starotestamentalnych zasad życia rodzinnego ${ }^{64}$.

\section{Rodzina, podobnie jak Kościól, winna być miejscem modlitwy i śpie-} wów religijnych. Kolejnym elementem, który zdaniem Jana Chryzostoma, upodabniał rodzinę chrześcijańską do kościoła, były praktykowane w niej wspólna modlitwa i śpiew psalmów. Zachęcał on wielokrotnie do tej praktyki, a zgromadzenie nawet kilku osób zebranych na modlitwie i śpiewaniu psalmów w rodzinie, nazywał wprost kościołem:

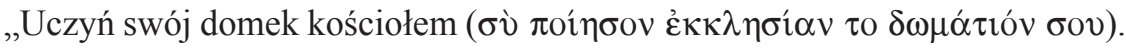
Gdzie bowiem jest śpiewanie psalmów, modlitwa i chór proroków oraz pobożna chęć śpiewania, to nikt nie popełni błędu, jeśli takie zgromadzenie na-

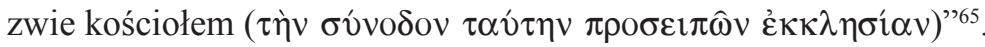

Tego rodzaju wspólna modlitwa i śpiewanie psalmów, pod przewodnictwem ojca, zwłaszcza przy stole, przed i po jedzeniu, nie tylko scala rodzinę i wyra-

${ }^{63}$ In Joannem hom. 32, 3, PG 59, 186-187.

${ }^{64}$ Por. O. Pasquato, Eredità giudaica e famiglia cristiana. La testimonianza di Giovanni Crisostomo, art. cyt., s. 71-75.

${ }^{65}$ Expositio in Ps 41, 2, PG 55, 158. 
ża świadomość wspólnoty, ale jest również obroną przeciwko zakusom szatana oraz przybliża i uobecnia Chrystusa. Wspólny śpiew w rodzinie nie tylko jest środkiem wychowawczym ${ }^{66}$, ale również sprawia, że dzięki niemu dom staje się kościołem:

„Ponieważ na ucztach diabeł bardzo często zastawia pułapki [...], bardzo dobrze jest przed i po posiłku zabezpieczyć się śpiewem psalmów, razem z żoną i dziećmi stojąc przy stole śpiewać Bogu święte hymny [...]”67.

„Odmawiając [przy stole] hymny, odprawiając modły, wprowadzając psalmy w miejsce owych nieszlachetnych śpiewek. W ten sposób Chrystus będzie obecny przy stole i napełni całą ucztę błogosławieństwem, gdy się modlisz, gdy śpiewasz pieśni duchowe, gdy zapraszasz ubogich do udziału w tym, coś zastawił, gdy postawisz na straży biesiady czujny porządek i umiarko-

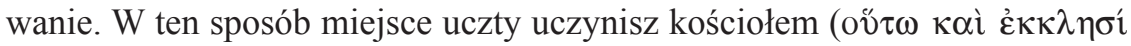

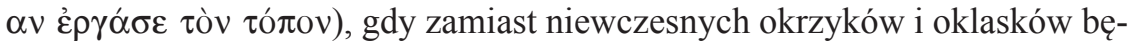
dziesz sławił Pana wszechrzeczy"68.

$\mathrm{Na}$ wzór kościoła, w którym nierzadko odbywają się różnego rodzaju nocne czuwania i wigilie, Biskup Konstantynopola zachęca swoich wiernych również do nocnej modlitwy rodzinnej, do której obok ojca i matki zaleca przyzwyczajać, choćby z małym udziałem, także małe dzieci, a przez to rodzina także w nocy staje się kościołem:

„Módl się i ty, mężczyzno, nie tylko twoja żona. Niech twój dom stanie się

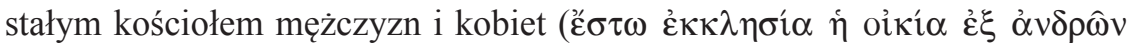

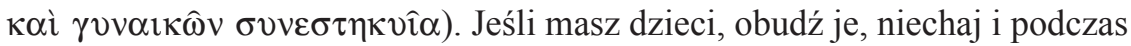

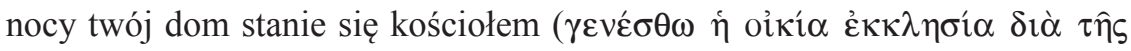

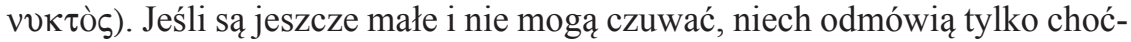
by jedną lub dwie modlitwy. Wstań tylko i uczyń to swoim zwyczajem" ${ }^{\prime \prime}$.

Nocna modlitwa, w której ofiaruje się Bogu część swego spoczynku, zdaniem naszego Biskupa, ma większą wartość u Boga - On prędzej jej wysłuchuje niż dziennej; ona też łatwiej oczyszcza duszę z brudu grzechów. Dlatego też zachęca do niej nawet $\mathrm{w}$ sypialni ${ }^{70}$. Zachęca również ojców, by uczyli

\footnotetext{
${ }^{66}$ Por. S. Longosz, Śpiew w rodzinie środkiem wychowania w pedagogii św. Jana Chryzostoma, „Roczniki Nauk o Rodzinie” 2009, nr 1 (56), 1-42.

${ }^{67}$ Expositio in Ps 41, 2, PG 55, 157.

${ }^{68}$ In epistulam ad Romanos hom. 24, 3, PG 60, 626, thum. T. Sinko: Św. Jan Chryzostom, Homilie na List św. Pawła do Rzymian, dz. cyt., I 2, s. 378; por. De Anna sermo 2, 5, PG 54, 650; S. Zincone, Valore e funzione della preghiera comunitaria secondo Giovanni Crisostomo, „Augustinianum” 35 (1995) 705-713; B. Fischer, Gemeinschaftsgebet in den christlichen Gemeinden und in der christlichen Familie in der alten Christenheit, „Liturgisches Jahrbuch” 24 (1974) 92-109.

${ }^{69}$ In Acta Apostolorum hom. 26, 4, PG 60, 203; zob. wyżej nota 40.

${ }^{70}$ Por. In Acta Apostolorum hom. 26, 4, PG 60, 202-204: „Swoją mowę kieruję zarówno do
} 
żony i dzieci od wczesnej młodości śpiewania psalmów i hymnów przy sto$1 \mathrm{e}^{71}$. Wielkie bowiem znaczenie przypisywał wspólnemu śpiewowi, zwłaszcza psalmów, gdy jeszcze był kaznodzieją w Antiochii ${ }^{72}$.

Także w dziedzinie wspólnych modłów i śpiewania psalmów, zwłaszcza przed i po posiłku, Jan Chryzostom nie był zupełnie oryginalny, bo miał tu swoje przykłady zarówno w rodzinie żydowskiej, jak i we wcześniejszej tradycji chrześcijańskiej. W judaizmie bowiem, jak wspominaliśmy wyżej, pierwszym świętym liturgicznym miejscem była nie tyle synagoga, co dom uważany za swego rodzaju sanktuarium. Dla Żyda dom był małą świątynią, a stół rodzinny traktowany jak ołtarz, jedzenie jako ryt święty, rodzice zaś jako celebrujący kapłani. Wszystkim codziennym zajęciom, zwłaszcza posiłkom, poprzedzanym i kończonym specjalnymi błogosławieństwami (Birkat ha-mosi, Birkat ha-mazon, Pwt 8, 10), towarzyszyły modlitwy i częsty śpiew psalmów ${ }^{73}$. Zwyczaje te przejęli w dużym stopniu i uzupełnili swoimi praktykami najpierw judeochrześcijanie, a potem również wywodzący się z pogan chrześcijanie, wzorując na nich swoją liturgię ${ }^{74}$ i tradycje. Stąd również wywodzi się głównie chrześcijański zwyczaj domowych modlitw przed i po jedzeniu ${ }^{75}$ oraz rodzinnego śpiewu psalmów i hymnów, poświadczany od początku przez literaturę wczesnochrześcijańską. Rodzinne posiłki przy jednym stole, $\mathrm{z}$ towarzyszeniem śpiewów i wspólnych modlitw, były również echem

mężczyzn jak i do kobiet. Zegnij kolana, żałuj, proś Boga, aby ci był miłosierny: On twoim nocnym modlitwom prędzej ulegnie, gdy do żalu dołączysz czas odpoczynku [...]. Wierz mi, nawet ogień tak nie niszczy rdzy, jak nocna modlitwa rdzę naszych grzechów [...]. Stróż nocny z wielką troską strzeże twojego majątku, ty zaś nie troszczysz się nawet o swoją duszę. Nie zmuszam cię, byś jak on pod gołym niebem czuwał, ani byś wykrzykiwał głośno hasła, ale w samej sypialni ( $\dot{\varepsilon} v \alpha \hat{v} \tau \hat{\omega} \tau \hat{\omega}$

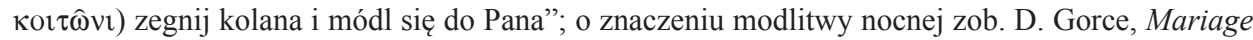
et perfection chrétienne d'après Saint Jean Chrysostome, „Etudes Carmelitaines” 2 (1936) 245-284, spec. 279-281.

${ }^{71}$ Por. In epistulam ad Colossenses hom. 9, 2, PG 62, 362-363: „Naucz je [dziecko] śpiewać psalmów pełnych mądrości. Kiedy od wczesnych lat będziesz ich dziecko uczył, poprowadzisz je powoli do coraz większych rzeczy. Psalmy mają w sobie wszystko, hymny zaś nic ludzkiego. Kiedy będzie umiało psalmy, nauczy się także hymnów jako pieśni jeszcze bardziej boskich”; zob. Longosz, Śpiew w rodzinie środkiem wychowania, s. 10-11..

72 Por. A. Nägele, Über Arbeitslieder bei J. Chrysostomos. Patristisch-literarisches zu K. Büchers „Arbeit und Rhythmus”, Leipzig 1905, 127; Rentinck, La cura pastorale in Antiochia nel IV secolo, s. 97-100.

${ }^{73}$ Por. Pasquato, Eredità giudaica e famiglia cristiana, s. 75-82.

${ }^{74}$ Por. W.O.E. Oesterley, The Jewish background of Christian Liturgy, Gloucester 1965, 125; C. Di Sante, Le preghiere d'Israele. Alle origini della liturgia cristiana, Casale 1985.

${ }^{75}$ Por. E. Goltz, Tischgebete und Abendmahlsgebete in der altchristlichen und in der griechischen Kirche, TU 14/2b, Leipzig 1905; J. Quasten, Musik und Gesang in den Kulten der heidnischen Antike und christlichen Frühzeit, Münster 1930; B. Fischer, La prière ecclésiale et familiale dans le christianisme ancien, „La Maison Dieu” 116 (1973) 41-58; G. Cuming, La base néotestamentaire de la prière commune, tamże, s. 19-40; A. Hamman, Liturgie, prière familiale dans les trois premiers siècles chrétiens, „Questions Liturgiques” 57 (1976) 81-98. 
odprawianych w kościele Eucharystii i agap. Do tej to długowiecznej tradycji nawiązywał Jan Chryzostom zachęcając do rodzinnego śpiewu psalmów i wspólnego odmawiania modlitw przy stole. To on właśnie przekazał nam tekst takiego błogosławieństwa po posiłku (bera-kah), które jako mniszą modlitwę przy stole zalecał także swoim wiernym do odmawiania ${ }^{76}$. Spotykamy je nieco wcześniej w Konstytucjach Apostolskich ${ }^{77}$, a później jako obowiązującą modlitwę przy stole, u mnichów Wschodu ${ }^{78}$. Modlitwę przed jedzeniem, połączoną ze znakiem krzyża, poświadcza już jednak na Zachodzie pod koniec II wieku w Afryce Tertulian ${ }^{79}$, który informuje nas również o nocnej modlitwie małżonków, którzy przerywają sen i modlą się razem głośno ${ }^{80}$, co 50 lat później potwierdzi również Hipolit Rzymski ${ }^{81}$. Podobnie śpiewanie psalmów i hymnów podczas posiłków, ale bez muzyki instrumentalnej, którą jako zwyczaj pogański potępiali prawie wszyscy Ojcowie Kościoła (wśród nich również Jan Chryzostom) ${ }^{82}$, poświadcza nam dla Aleksandrii Klemens

${ }^{76}$ Por. In Matthaeum hom. 55, 5, PG 58, 545, tłum. J. Krystyniacki, ŹMT 23, 165: „A jeśli chcecie usłyszeć ich hymn, abyście go też sami powtarzali, to wypowiem wam tę nabożną pieśń. Jej słowa są następujące: «Bądź pochwalony, Boże, który mnie żywisz od mej młodości, który dajesz pokarm wszelkiemu ciału, napełnij nasze serca radością i weselem, abyśmy mając zawsze wszelki dostatek, obfitowali we wszystkie dobre uczynki w Chrystusie Jezusie, Panu naszym, z którym Tobie [Ojcze], chwała, cześć i moc wraz z Duchem Świętym na wieki. Amen. Chwała Tobie Panie, chwała Tobie - Święty, chwała Tobie - Królu, że dałeś nam pożywienie ku radości. Napełnij nas Duchem Świętym, abyśmy przed Twym obliczem zostali uznani za miłych i abyśmy nie zostali zawstydzeni wtedy, kiedy oddasz każdemu według jego uczynków» (Mt 16, 27)".

${ }^{77}$ Por. Constitutiones Apostolicae VII 49, ed. Funk, I, s. 458, lub SCh 336, 114, thum. L. Małunowiczówna: Antologia modlitwy wczesnochrześcijańskiej, STCh 3, Lublin 1993, 200 (modlitwy przed i po posiłku); zob. R. Kaczynski, Das Wort Gottes in Liturgie und Alltag der Gemeinden des Johannes Chrysostomus, Freiburg 1974, 338.

${ }^{78}$ Jej tekst tamże, s. 200; por. E. Goltz, Tischgebete und Abendmahlsgebete, dz. cyt., s. 50-65.

${ }^{79}$ Por. Apologeticum 39, 17-18, CCL 1, 152-153, thum. J. Sajdak, POK 20, 162-163: „Nie siada się do stołu, zanim nie skosztuje się przedtem modlitwy do Boga [...]. Podobnie jak zaczyna, tak i kończy ucztę modlitwa [...]. Tak posilają się ludzie, którzy pamiętają, że także w nocy do Boga modlić się muszą”; De oratione 25, 6, CCL 1, 273, tłum. W. Kania, PSP 5, 130: „Również wypada wiernym modlić się przed posiłkiem"; De corona 3, 4, CCL 2, 1043.

${ }^{80}$ Por. Ad uxorem II 5, 2, CCL 1, 389, tłum. K. Obrycki, PSP 29, 161: „Czy pozostanie to nie zauważone, kiedy siebie i swoje łoże znaczysz znakiem krzyża? [...]. Kiedy także w czasie nocy wstajesz, by się pomodlić? Czyż nie będzie to wyglądać, że zajmujesz się jakąś magiczną praktyką?".

${ }^{81}$ Por. Traditio Apostolica 41, ed. B. Botte, SCh 11bis, 128-130, thum. M. Michalski, ALP I 315: „Módl się również, zanim ciało swe złożysz na spoczynek nocny. O północy zaś powstań, obmyj ręce, i znów się pomódl. Jeśli obecna jest twa żona, módlcie się razem; jeśli zaś nie jest ona jeszcze chrześcijanką, wyjdź do innej izby i tam pomodliwszy się powróć. Nie ociągaj się z tą modlitwą. Okoliczność, że jesteś związany stosunkiem małżeńskim, nic tu nie przeszkadza: nie jest bynajmniej skalany, kto żyje w małżeństwie [...]. Tak więc powinieneś się modlić również o północy, czyli o godzinie, w której - jak nam przekazała tradycja Ojców - cała przyroda wstrzymuje na chwile swój bieg, by chwalić Pana".

${ }^{82}$ Por. S. Longosz, Muzyka instrumentalna w ocenie wczesnochrześcijańskich pisarzy, w: Musica 
Aleksandryjski, informując, że był to śpiew alternatywny ${ }^{83}$, a nieco później dla Kartaginy - św. Cyprian ${ }^{84}$. Zwyczaj ten, jak widać, ogarniał powoli cały Kościół powszechny.

\section{W rodzinie, jak w Kościele, wszyscy są równi i wzajemnie się wspo-} magają. Rodzina chrześcijańska podobna jest, zdaniem Jana Chryzostoma, do kościoła nie tylko poprzez analogiczne praktykowane w niej działania, ale i poprzez panującą w niej atmosferę i realizację podobnych celów. Podobnie jak w kościele, w rodzinie chrześcijańskiej wszyscy, także niewolnicy, służba i dzieci, mają być traktowani na równi jak bracia, mają się wzajemnie kochać i uświęcać, i w ten sposób wspólnie zmierzać do zbawienia, a troszczyć się o to mają przez cały czas przede wszystkim rodzice, przez swój przykład i zachowanie:

„Mąż, wstawszy rano, niech myśli jedynie o tym, co czynić lub mówić, czym mógłby cały dom uczynić pobożniejszym. Z kolei żona niech jeszcze bardziej troszczy się o to, aby cały dom spełniał uczynki prowadzące do nieba. Jeśli w rzeczach doczesnych staramy się spełniać obowiązki publiczne przed sprawami domowymi, aby nie karano nas z powodu ich zaniedbania, nie wleczono na rynek i nie znieważano, tym bardziej należy tak postępować w rzeczach duchowych, aby najpierw wypełniać obowiązki względem Boga" ${ }^{" 85}$.

W odpowiedzi na to również dzieci winny czcić i szanować swoich rodziców, aby przez to wynagrodzić ich troski, trudy i starania, jakie oni dla nich ponieśli:

„Należy im [rodzicom] świadczyć każdą powinność i przedkładać ich ponad innych, ponieważ nas urodzili, wychowali i ponieśli dla nas tysiące cierpień" $"$.

Antiqua, VI, Bydgoszcz 1982,355-388; tenże, Środowisko muzyczne Konstantynopola w ocenie Jana Chryzostoma, w: Musica antiqua, VII, Bydgoszcz 1985, 299-316.

${ }^{83}$ Por. Stromata VI 11, 90, 1, SCh 446, 240-242, tłum. J. Niemirska-Pliszczyńska: Klemens Aleksandryjski, Kobierce, II, Warszawa 1994, 165.

${ }^{84}$ Por. Ad Donatum 16, CCL 3A, 13: „Sonet psalmus convivium sobrium: ut tibi tenax memoria est, vox canora, adgredere hoc munus ex more".

${ }^{85}$ In Matthaeum hom. 77, 6, PG 58, 709-710, thum. J. Krystyniacki, ŹMT 23, 413; por. L. Meyer, Perfection chrétienne et vie solitaire dans la pensée de Jéan Chrysostome, RAM 14 (1933) 293-294.

${ }^{86}$ In Joannem hom. 85, 2, PG 59, 462; por. także: In Genesim sermo 4, 3, PG 54, 597-598; „Czy jest coś, czego by syn nie mógł uczynić dla ojca? Nic oprócz tego, że oni sami cię urodzili, a ty ich bynajmniej urodzić nie możesz. Ponieważ w tej rzeczy jesteśmy od nich niżsi, w tym ich przewyższamy, że obdarzamy ich czcią i szacunkiem, nie tylko $z$ racji prawa natury, lecz przed naturą z powodu bojaźni Bożej. Bóg bowiem chce, żeby rodzice byli wielce czczeni przez swoje dzieci"; O. Pasquato, Rapporto tra genitori e figli. Eredità giudaica in Giovanni Crisostomo, „Augustinianum” 28 (1988) 391-404; tenże, Pastorale familiare: testimonianza di Giovanni Crisostomo, „Salesianum” 51 (1989) 15-26. 
Kiedy zaś wszyscy w domu tak żyją według chrześcijańskich zasad miłości, połączeni ze sobą węzłami wzajemnej miłości i usłużności, sam Chrystus z aniołami jest, zdaniem złotoustego Kaznodziei, obecny wśród nich, a cała ich wspólnota rodzinna zamienia się faktycznie w mały kościół domowy:

„Gdzie bowiem duchowa nauka, tam i umiarkowanie i skromność i dobroć; gdzie mąż, żona i dzieci, połączeni zgodą, przyjaźnią i węzłami cnót, tam w pośrodku przebywa Chrystus" ${ }^{\text {87; }}$

„Oni będą z tobą obcować z zaufaniem i większą swobodą, a dom twój za-

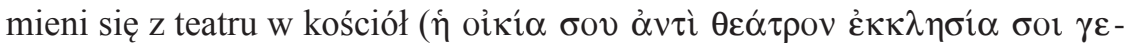

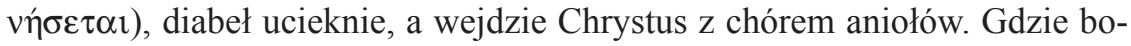
wiem jest Chrystus, tam i aniołowie, gdzie zaś Chrystus i aniołowie, tam jest niebo" $"$.

W skład starożytnych rodzin chrześcijańskich wchodzili również, jak wspominaliśmy, niewolnicy. Jan Chryzostom nie występował nigdy wprost przeciwko niewolnictwu, ani też nie zabraniał posiadania niewolników ${ }^{89}$, ale wielokrotnie podkreślał, zwłaszcza na zgromadzeniach liturgicznych, że Kościół nie czyni różnicy między niewolnikami a wolnymi, bo również niewolnicy są wezwani do zbawienia, a wobec Boga także wolni są tylko sługami i niewolnikami:

„Przecież nazwa Kościół nie pozwala panom czuć się dotkniętymi, jeżeli zostaną do niego zaliczeni razem z niewolnikami, albowiem Kościół nie zna różnicy między panem i niewolnikiem, określając jednych i drugich tylko na podstawie dobrych i złych uczynków. Jeśli więc gdzie jest zgromadzenie kościelne, nie oburzaj się na to, że wspólną z tobą przemową objęty został niewolnik: «W Chrystusie Jezusie bowiem nie ma ani niewolnika ani wolnego» $(\mathrm{Ga} 3,28){ }^{\prime \prime 90}$.

Nasz złotousty Kaznodzieja podkreślał, że nie ma nic piękniejszego od takiej rodziny, w której wszyscy równi, mężczyźni, kobiety i dzieci, wolni i niewolnicy, przestrzegają na równi przykazania miłości Boga i bliźniego, gdy

${ }^{87}$ In Genesim sermo 7, 5, PG 54, 616; zob. tamże, sermo 8, 2, PG 54, 620.

${ }^{88}$ In Matthaeum hom. 48, 7, PG 58, 495, thum. A. Baron, ŹMT 23, 88.

${ }^{89}$ Por. W. Jaeger, Die Sklaverei bei Johannes Chrysostomus, Diss., Kiel 1974; M. Signifredi, La schiavitù in Giovanni Crisostomo, „Studi e materiali di storia delle religioni” 25 (2001) 271-289; Szczur, Problematyka społeczna w późnoantycznej Antiochii, s. 376-409 (Kwestia niewolnictwa sytuacja życiowa niewolników).

${ }^{90}$ In epistulam ad Philemonem hom. 1, 1, PG 62, 705, thum. T. Sinko: Św. Jan Złotousty, Homilie na listy pasterskie św. Pawła, s. 369; por. In epistulam I ad Corinthios hom. 19, 4-5, PG 61, 156159; Catechesis 1, 27, SCh 50bis, 122, tłum. W. Kania: Św. Jan Chryzostom, Katechezy chrzcielne, Lublin 1993, 31-32: „«Pójdźcie do mnie wszyscy» (Mt 11, 28) - władcy i poddani, bogaci i ubodzy, wolni i niewolnicy mężowie i żony, młodzi i starcy, zdrowi i ułomni - oto dary Pana. Nie czyni różnicy między niewolnikami i wolnymi, bogatymi i biednymi, znosi wszelką nierówność". 
rywalizują w zachowywaniu Bożych przykazań zasiadając zaś wspólnie przy stole unikają pijaństwa i obżarstwa, mąż i żona czuwają, by dochować sobie wzajemnie wierności, gdy pan nie wstydzi się być upominany przez niewolnika, a niewolnicy karceni przez pana; uważał, że taki dom można bez pomyłki i przesady nazwać wprost kościołem Bożym:

„Zauważ, jak wielka jest troska o to, by w domu i przy stole mężczyźni z kobietami, a niewolnicy z wolnymi, rywalizowali z sobą o zachowanie tego przykazania, i jakże szczęśliwi są ci, którzy w ten sposób wspólnie spożywa-

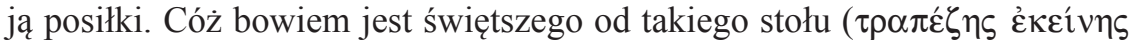

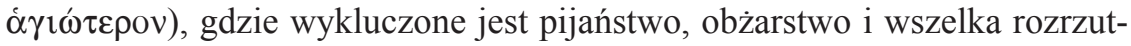
ność, a $\mathrm{w}$ ich miejsce wprowadzone prawdziwe współzawodnictwo w przestrzeganiu Bożych praw: gdy mąż czuwa nad żoną, a żona nad mężem, by nie popaść w przepaść wiarołomstwa i nie ściągnąć na siebie najcięższej kary; nikt się nie wstydzi, że pan jest upominany przez niewolników lub niewolnicy karceni przez panów. Nikt się nie pomyli, jeśli taki dom nazwie kościołem

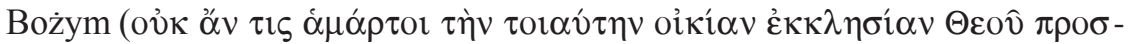
$\varepsilon 1 \pi \hat{\omega})^{\prime \prime 91}$.

Zachęcał z jednej strony niewolników, by swą ciężką pracę wykonywali tak, jakby służyli samemu Bogu ${ }^{92}$, a z drugiej panów, by ich traktowali humanitarnie i dopuszczali do uczestnictwa w sprawach rodzinnych ${ }^{93}$.

Występował jednak przeciw bogatym, którzy otaczali się dużymi gromadami niewolników, zachęcając, by ograniczali ich liczbę do kilku, a najlepiej - by się obywali bez ich pomocy:

„Dlaczego masz aż tylu niewolników? Jak przy ubieraniu i przy stole wymagany jest jeden, tak i przy innym posługiwaniu. Jaka potrzeba? - żadna. Wystarczyłoby, aby jeden pan korzystał z posługi tylko jednego niewolnika, albo nawet dwóch lub trzech panów z jednego niewolnika [...]. Dlatego to Bóg dał nam ręce i nogi, abyśmy nie korzystali ze służących. Nie z potrzeby bowiem wprowadzono stan niewolniczy $[. .$.$] i nie ma potrzeby posiadania$

${ }^{91}$ Homilia de decem millium talentorum debitore 2, PG 51, 18-19.

${ }_{92}$ Por. In epistulam ad Titum hom. 4, 4, PG 62, 686, tłum. T. Sinko, Homilie na listy pasterskie św. Pawła, s. 342: „Nie patrz tedy, mój kochany, na to, że służysz człowiekowi, lecz, że służysz Bogu, że jesteś ozdobą Ewangelii, a zdołasz wszystko uczynić, słuchając pana i znosząc jego niewczesne gniewy [...]. Pomyśl, że nie dla niego to robisz, lecz dla wypełnienia przykazania Bożego, a łatwo zniesiesz wszystko, cokolwiek by to było".

${ }^{93}$ Por. In epistulam ad Philemonem hom. 2, 3, PG 62, 711, thum. T. Sinko, Homilie na listy pasterskie św. Pawta, s. 379: „Napisane to jest nie bez przyczyny, lecz na to, byśmy jako panowie nie porzucali nadziei co do niewolników i nie postępowali z nimi srogo, lecz abyśmy nauczyli się przebaczać przewinienia takim sługom; abyśmy nie byli zawsze twardzi i abyśmy nie wstydzili się z powodu ich niewoli brać ich za uczestników we wszystkich sprawach, jeżeli tylko są dobrzy. Jeśli bowiem Paweł nie wstydził sie nazywać niewolnika synem i sercem, i bratem ukochanym, czemuż my mielibyśmy się wstydzić?". 
niewolników. Jeśli zaś jest potrzeba, to najwyżej jednego lub dwóch [...]. Jeśli zaś gromadzisz ich więcej, to nie z dobrotliwości lub humanitarności, ale dla własnej przyjemności"’94.

Zachęcał również ich właścicieli, aby ich humanitarnie traktowali, aby ich zbytnio nie karali, nie bili, nie krzyczeli i nie wykorzystywali, bo budzi to często zgorszenie, ale postępowali z nimi po ludzku ${ }^{95}$, do czego zresztą wzywało zarówno prawo kościelne ${ }^{96}$ jak i świeckie ${ }^{97}$. Zobowiązywał także ojców, by przyzwyczajali swe dzieci do samodzielności i obywania się bez pomocy służących, oraz by je pouczali o panujących stosunkach społecznych i o relacjach między niewolnikami i wolnymi, by te pamiętały, że niewolnictwo jest skutkiem grzechu, by obchodziły się z nimi jak z braćmi, by były ich panami nie przez swą pozycję, ale przez cnoty i postawę moralną, proponując im nawet na ten temat schemat odpowiedniej katechezy:

„Gdy chłopiec chce wziąć kąpiel, niech nie woła sługi, lecz niech sam się obsłuży; wtedy wolnego będą kochać i pozostaną mu wierni. Niech sobie chłopiec sam przyniesie ubranie z szafy. W kąpieli niech nie woła sługi. Niech sam sobie wystarczy we wszystkim, co go hartuje i uczyni miłym i uprzejmym dla drugich. Poucz też syna o naturze stosunków społecznych i wyjaśnij mu, kim jest niewolnik, a kim wolny. Powiedz mu: «Synu! Na początku nie było niewolników; dopiero grzech wprowadził na świat niewolnictwo. Ponieważ syn [Cham] zelżył ojca, za karę został niewolnikiem swych braci (Rdz 9, 20-25). Bacz więc, byś się nie stał niewolnikiem niewolników. Jeśli, jak oni, wpadasz w gniew, postępujesz we wszystkim jak oni, jeśli nie masz cnoty jak niewolnik, nie zachowasz też większej godności jak niewolnik. Staraj się być i pozostać ich panem nie przez swą pozycję, lecz przez cnoty, abyś będąc wolnym, nie stał się niewolnikiem wśród niewolników. Nie widzisz, jak niektórzy ojcowie odrzucili swe dzieci, a na ich miejsce wprowadzili jako spadkobierców niewolników? Strzeż się, by to nie spotkało i ciebie! Nie pragnę

${ }^{94}$ In epistulam I ad Corinthios hom. 40, 5, PG 61, 353-354.

${ }^{95}$ Por. In epistulam ad Ephesios hom. 15, 3, PG 62, 109: „Dotyczy to zwłaszcza kobiet, które gdy się rozgniewają na służące, cały dom napełniają krzykiem. Często zaś, jeśli dom stoi przy wąskiej ulicy i wszyscy koło niego przechodzą, słyszą, jak ona krzyczy, a służąca lamentuje. Cóż brzydszego i nieprzyzwoitszego, niż słyszeć takie płacze i jęki. Wszyscy zaglądają, co się tam dzieje i pytają: to ona bije swoją niewolnicę? Cóż jest bezwstydniejszego od tego? Czy więc nie należy bić? Nie mówię tego, należy, ale nie ustawicznie i nie ponad miarę".

${ }^{96}$ Por. Constitutiones Apostolorum IV 12, 1-2, ed. Funk s. 233 lub SCh 329, 190: „Odnośnie do służących cóż więcej można powiedzieć, jeśli nie to, żeby niewolnik przejawiał dobrą wolę wobec pana ze względu na bojaźń Bożą, nawet jeśli jego pan jest bezbożny lub zły i nie zgadzają się co do religii. Również i pan niech kocha swego służącego, i choć wyżej od niego stoi, niech go uważa za

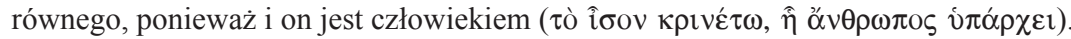

${ }^{97}$ Por. Cod. Theod. IX 12, 1-2, ed. P.M. Mommsen (Berolini 1905), s. 455-456. 
i nie życzę ci tego, jedno i drugie zależy od ciebie»! Tymi słowy wychowuj syna w łagodności i każ mu obchodzić się ze sługami jak z braćmi"98.

Zalecał także ojcom, by jako gospodarze i głowy rodzin pouczali swoich niewolników o wierze chrześcijańskiej, tak jakby uczyli własne dzieci, by ich uczyli cnoty posłuszeństwa, by ich darzyli swego rodzaju miłością, by się troszczyli o ich zbawienie, bo i oni sami z cnót i wiedzy niewolników często korzystają: wszystko to bowiem należy do obowiązków ojca rodziny:

„Nie na próżno i bez zastanowienia Paweł poleca panom uczyć ich cnoty posłuszeństwa; nie tyle, by służyli panom, ile by słowo Boże i nauka nie pozostały bezowocne. Wiem także, iż wiele domów korzysta z cnoty niewolników. Jeśli niewolnik, który jest pod władzą, może poprawiać pana, to o ileż bardziej pan - niewolników. Wy tę duchową posługę ze mną, proszę, rozdzielajcie, ja gdy przemawiam do wszystkich, a wy oddzielnie - każdemu, zatroszczcie się o zbawienie każdego z domowników. To bowiem jest obowiązkiem tych, którzy jako ojcowie rodzin stoją na czele swoich domów i mają się o nie troszczyć" 99 .

Z pełnej wzajemnej miłości atmosfery rodziny chrześcijańskiej winni odnosić korzyść nie tylko niewolnicy, ale i sąsiedzi i krewni, bo dobry chrześcijański dom winien wywierać pozytywny wpływ na swe otoczenie: zgoda bowiem w domu między małżonkami, dziećmi i służbą jest jak dobra woń, z której winni się cieszyć także i inni:

„Jeśli małżonkowie żyją w zgodzie, dzieci są dobrze wychowane, a domownicy przestrzegają porządku, wówczas budują się tym także krewni, przyjaciele i sąsiedzi. Jeśli zaś jest przeciwnie, wszystko się wywraca i burzy"100.

${ }^{98}$ De inani gloria et liberis educandis 70-72, SCh 188, 170-174, thum. W. Kania, BOK 19, 97-98.

${ }^{99}$ In epistulam II ad Thessalonicenses hom. 5, 5, PG 62, 499; In epistulam ad Ephesios hom. 22, 2, PG 62, 158: „Jeśli zaś chcecie posłuchać, to powiemy to samo o niewolnikach, co wcześniej powiedzieliśmy o dzieciach: pouczajcie ich, by byli pobożnymi i religijnymi”; In epistulam ad Colossenses hom. 10, 1, PG 62, 367: „Niewolnicy, bądźcie we wszystkim posłuszni doczesnym panom $(\mathrm{Kol} 3,12)$. I tu również jest pewna miłość, ale nie tak naturalna, jak wyżej (ojciec-dzieci), lecz ze zwyczaju, wypływająca z samej władzy i faktów".

${ }^{100}$ In epistulam ad Ephesios hom. 20, 1, PG 62, 136, thum. M. Jurek, BOK 19, 48; por. In Genesim hom. 38, 7, PG 53, 360: „W domu niech panuje i umacnia się pokój. Żona niech będzie oddana swemu mężowi, a mąż niech ma możliwość ucieczki w swojej żonie od spraw wewnętrznych i niepokojów, jak do portu, gdzie może znaleźć pociechę w każdym kłopocie. Na to dana mu jest żona do pomocy, aby rozradowany jej zachętą, był zdolny oprzeć się wszelkiemu złu, które musi znosić. I dlatego, kiedy żona jest cnotliwa i spokojna, nie tylko umacnia swego męża swoim towarzystwem, lecz jest mu pożyteczna w wielu innych sprawach. Robi wszystko dogodnym i łatwym dla niego. Nie pozwala, żeby martwił się zewnętrznymi trudnościami albo tymi, które powstają każdego dnia w domu. Dlatego, jak dobry zarządca, zamienia swoją mądrością każdy niepokój ducha w pogodę i przynosi pociechę swoją wielką roztropnością. Ci, którzy żyją tak zjednoczeni ze sobą, nie odczuwają ciężaru trudności. Dlatego, kiedy panuje taka zgoda i pokój, kiedy istnieje 
Ten apostolski aspekt rodziny staje się jeszcze bardziej widoczny, gdy dom jest gościnny, otwarty również dla ubogich i pielgrzymów, jak ongiś dom Pryski i Akwili:

„Tak byli wypróbowani, że nawet, pomieszczenie swoje uczynili kościołem

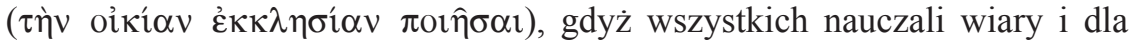
wszystkich obcych otworzyli swój dom. Paweł nie miał zasadniczo zwyczaju nazywać domów kościołami, jeśli nie było w nich wzniosłej religijności i głębokiej bojaźni Bożej”101.

Jan Chryzostom przypomina, że jak Kościół od swego początku był czuły na biednych i potrzebujących, przeprowadzał dla nich zbiórki i był zawsze dla nich gościnny, tak i teraz każdy dom chrześcijański winien być dla nich zawsze otwarty, pamiętając, że w osobie gościa czy żebraka przychodzi do niego sam Chrystus. Zachęcał więc, by nie traktować ich, jak natrętów, ale chętnie i z ochotą ich przyjmować ${ }^{102}$, przygarniać wszystkich, zwłaszcza potrzebujących, nawet gdyby z pozoru wyglądali na ludzi lichych i w brudnych łachmanach $^{103}$, by nie zniechęcać ich do wejścia przez przeprowadzanie zbytniego

więź miłości między żoną i mężem, wszystko obróci się na dobro, a oni sami nie będą narażeni na zasadzkę, bo otoczeni są jakby murem mocnym i nie do zdobycia tj. zgodą według woli Bożej”.

${ }^{101}$ In epistulam ad Romanos hom. 30, 3, PG 60, 664, thum. T. Sinko: Św. Jan Chryzostom, Homilie na List św. Pawła do Rzymian, dz. cyt., I 2, s. 442; zob. wyżej nota 30; tamże, Hom. 24, 3, PG 60, 626; Epistula ad Ephesios hom. 20, 9, PG 62, 147-148, BOK 19, 67: „Jeśli ktoś chce przyjmować gości i wydawać uczty, nie czyni nic zdrożnego ani niewłaściwego. Ale wtedy zapraszaj też biednych, którzy mogą wam błogosławić dom i swoją obecnością, wnosić pełne błogosławieństwo Boga".

${ }^{102}$ Por. In epistulam ad Romanos hom. 21, 5, PG 60, 606, thum. T. Sinko: Homilie na List św. Pawła do Rzymian I 2, 545-346: „[Paweł] nie mówi: Wykonujcie gościnność, lecz: zabiegajcie o nią, ucząc nas, żebyśmy nie czekali na potrzebujących, aż ktoś poprosi i przyjdzie do nas, lecz żebyśmy sami wychodzili im naprzeciw, wręcz poszukując ich [...]. Kiedy zobaczymy obcego lub biedaka, to ściągamy do góry brwi i nawet nie uważamy ich za godnych naszych słów, i dopiero zmiękczeni tysiącznymi błaganiami, każemy służbie dać im drobny zasiłek, sądząc, że spełniliśmy już dobrze nasz obowiązek".

${ }^{103}$ Por. tamże, hom. 30, 4, PG 60, 666, T. Sinko, s. 446: „Nie patrz zaś na to, że ci, którzy do ciebie przybywają, wyglądają nieraz z pozoru na ludzi lichych, na żebraków i łachmaniarzy, lecz pamiętaj, o głosie mówiącym: «Cokolwiek uczyniliście jednemu z tych braci moich najmniejszych, Mnieście uczynili» (Mt 25, 40); oraz: «Nie gardźcie żadnym z tych małych; [...] aniołowie ich [...] wpatrują się zawsze w oblicze Ojca mojego, który jest w niebie» (Mt 18, 10). Przyjmuj więc z ochotą tych, którzy wraz z pozdrowieniem pokoju, przynoszą ci tysiączne dobra (Mt 10, 12-13 i 42)”; tamże, hom. 22, 2, PG 60, 610, T. Sinko, s. 352: „Przyszedł do ciebie do domu ubogi? Bądź jak on! Nie rób się ważniejszy z powodu bogactwa! W Chrystusie nie ma ani bogatego, ani ubogiego $(\mathrm{Ga} 3,28)$. Nie wstydź się go z powodu zewnętrznej odzieży, lecz przyjmij go ze względu na wewnętrzną wiarę! Gdy zobaczysz, że jest smutny, nie uważaj go za niegodnego pociechy, ani też gdy zobaczysz, że jest szczęśliwy, nie wstydź się podzielać jego radości i weselić się razem z nim; lecz bądź jak on, mniemając o nim to samo, co mniemasz o sobie"; In Matthaeum hom. 48, 7, PG 58, 492, ŹMT 23, 87: „Nie zważaj na to, że przychodzi do ciebie ubogi, opuszczony i w łachmanach, 
wywiadu ${ }^{104}$, choć z drugiej strony zalecał ostrożność, by nie przyjmować i nie karmić darmo pasożytów i oszustów ${ }^{105}$. Podkreślał przy tym, że takie zasady praktykowania domowego miłosierdzia i gościnności ustanowił Bóg w Starym i Nowym Testamencie ${ }^{106}$, zaznaczając, że jeśli nie będziemy ich przestrzegać, sami nie uzyskamy miłosierdzia u Boga ${ }^{107}$.

W ramach świadczenia uczynków miłosierdzia Złotousty proponuje udzielanie bezpośrednio ubogim konkretnej pomocy materialnej ${ }^{108}$, podkreślając, że do jej niesienia zobowiązani są wszyscy, zarówno bogaci jak i biedni, wolni jak i niewolnicy ${ }^{109}$, co więcej, komentując zdanie św. Pawła: „Niechaj pierw-

ale pamiętaj, że przez niego Chrystus wchodzi do twego domu (Mt 25, 40); zaniechaj surowości i obelżywych słów, którymi obrzucasz przychodzących, nazywając ich natrętami, próżniakami i innymi jeszcze gorszymi wyzwiskami”.

${ }^{104}$ Por. In epistulam ad Romanos hom. 21, 4, PG 60, 606-607, T. Sinko, s. 346-347: „Także ty nie wypytuj ich [tj. przybyszów] dociekliwie, gdyż przez nich przyjmujesz Chrystusa, a gdy będziesz nazbyt skrupulatny, nieraz pominiesz wypróbowanego męża i stracisz zapłatę za to [...]. Nie wypytuj więc o życie i czyny, gdyż jest to dowodem najwyższego nietaktu za jeden chleb wypytywać się o całe życie. Gdyby nawet ów człowiek był mordercą, rozbójnikiem, czy kimkolwiek bądź, czyż w twoim mniemaniu nie byłby godny kawałka chleba i kilku groszy? Przecież twój Pan każe dla niego słońcu wschodzić (Mt 5, 45), a ty uważasz, iż nie jest godzien nawet jednodniowego pożywienia?".

${ }^{105}$ Por. In Matthaeum hom. 48, 7, PG 58, 495-496, ŹMT 23, 87-88: „Niech więc siadają wspólnie $\mathrm{z}$ tobą do stołu ludzie ubodzy i wolni, a nie krzywoprzysięzcy, nie mimowie [...]. Nie zatrzymuj przyjaciół, którzy są nauczycielami twej szkody, którzy pragną raczej twego stołu, niż twej przyjaźni”.

${ }^{106}$ Por. De eleemosyna 5, PG 51, 269, tłum. T. Sinko, Dwadzieścia homilij i mów, s. 109-110: „Bardzo bowiem Bóg dba o miłosierdzie, nie tylko o swoje wobec nas, lecz także o to, któreśmy powinni okazywać współniewolnikom. I w Starym i w Nowym Zakonie wiele w tej sprawie ustanowił praw; rozkazując być ludzkim za pomocą wszelkich środków: i przez słowa, i przez pieniądze, i przez uczynki. O tym Mojżesz rozrzuca mowy tu i tam we wszystkich prawach, i prorocy w imieniu Boga o tym wołają: «Miłosierdzia żądam, nie ofiary» $(\mathrm{Oz} 6,6)$; a wszyscy apostołowie zgodnie z tym postępują i mówią".

${ }^{107}$ Por. In epistulam ad Romanos hom. 18, 7, PG 60, 582, thum. T. Sinko, Homilie na List św. Pawła do Rzymian, s. 300: „Jakież oni uzyskają przebaczenie, skoro za życia nie nakarmili Go (por. Mt 25, 42), a kiedy już mieli odejść do Niego, nawet z pieniędzy, których już nie są panami, nie chcieli Mu wydzielić jakiejś cząstki, lecz tak niechętnie i wrogo są wobec Niego usposobieni, że Mu nie dają cząstki z tego, co dla nich już będzie bezużyteczne?"; In Matthaeum hom. 52, 5, PG 58, 524, ŹMT 23, 132: „Uczmy się być miłosierni z wszelkich powodów, u przede wszystkim dlatego, że również i my potrzebujemy wielkiego miłosierdzia".

${ }^{108}$ Por. In Matthaeum hom. 85, 4, PG 58, 763, ŹMT 23, 488-489: „Gdyby każdy [chrześcijanin] dał ubogiemu bochenek chleba, żyliby wszyscy w obfitości. Gdyby każdy dał jednego obola, nie byłoby żadnego ubogiego"; tamże, hom. 66, 3, PG 58, 630, ŹMT 23, 296-297.

${ }^{109}$ Por. De eleemosyna 3, PG 51, 265, tłum. T. Sinko, Dwadzieścia homilij i mów, s. 103-104: „Nie do bogatych tylko się zwracam, [...] lecz i do biednych; nie tylko do wolnych, ale i do niewolników; nie tylko do mężczyzn, ale i do kobiet. Niech nikt nie będzie uwolniony od tego świadczenia, ani nie zostanie bez udziału w tym zysku, lecz niech każdy daje. Albowiem ubóstwo nie może stanowić przeszkody w takiej składce". 
szego dnia tygodnia każdy z was coś odłoży według tego, co uzna za właściwe, żeby nie zarządzać zbiórek dopiero wtedy, kiedy przybędę" (1Kor 16, 2) zachęca do dobrowolnego opodatkowania się na ten cel, do ustalenia sobie stałej domowej opłaty, nazywanej przez niego podatkiem $(\tau \dot{\varepsilon} \lambda \varepsilon \sigma \mu \alpha)$ na biednych, przekazywanym potem $\mathrm{w}$ kościele ${ }^{110}$. Biedniejszym chrześcijanom, którzy wstydzą się składać w kościele zbyt małe i symboliczne datki na jałmużnę dla ubogich, proponuje, aby w swych domach, w miejscach, gdzie się modlą, ustawili sobie przy łóżku niewielkie drewniane skrzyneczki lub szkatuły, do których by przez dłuższy okres czasu (np. przez okres Wielkiego Postu lub kilku niedziel) w każdą niedzielę lub przy każdej modlitwie, odkładali na jałmużnę niewielkie sumki pieniędzy, a po zakończeniu danego okresu przekazywali w kościele całą zebraną sumę. Zebrane w ten sposób pieniądze na ubogich nazywa ,świętymi pieniędzmi” podkreślając, że są one równocześnie gwarantem bezpieczeństwa całego dobytku tych, którzy odkładają je dla biednych. W ten sposób każdy tak postępujący członek rodziny czyni swój dom kościołem, szkatułkę - skarbcem kościelnym, siebie zaś samego - kościelnym ekonomem ubogich, który pełni już funkcję kapłańską:

„«Każdy z was», nie absolutnie ten lub ów, lecz «każdy», czy byłby ubogim czy bogatym, czy mężczyzną czy kobietą, czy niewolnikiem czy wolnym, niech sobie coś odłoży. Nie powiedział, niech zaniesie do kościoła, ale aby z powodu małości [sumy] nie musiał się wstydzić [...], powiedział: odłóż u siebie i dom swój uczyń kościołem, szkatułką-skarbcem ( $\pi \alpha \rho \alpha \grave{~} \sigma \alpha v \tau \hat{\omega} \tau i ́ \theta \varepsilon \imath$

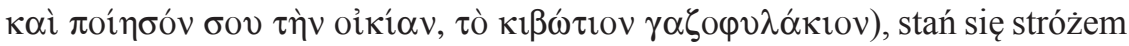
świętych pieniędzy, przez siebie samego ustanowionym ekonomem ubogich.

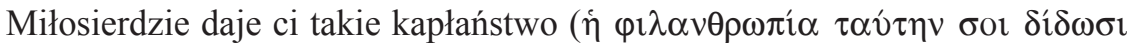

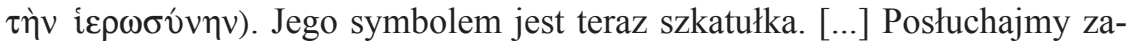
tem św. Pawła i uczyńmy sobie w domu szkatułkę dla ubogich, która byłaby umieszczona obok miejsca, w którym stajesz do modlitwy; ilekroć będziesz podchodził do modlitwy, złóż najpierw jałmużnę, a następnie wypowiedz modlitwę; i jak nie chciałbyś przystępować do modlitwy z nieumytymi rękami, tak nie czyń też tego bez jałmużny: nie mniej ważną jest bowiem złożona tam jałmużna, niż powieszona obok łóżka ewangelia. Jeśli bowiem ewangelię tylko powiesisz, nic nie czyniąc, to nie doznasz wielkiej korzyści, mając zaś taką szkatułkę, masz broń przeciwko diabłu, uwznioślasz swoją modlitwę,

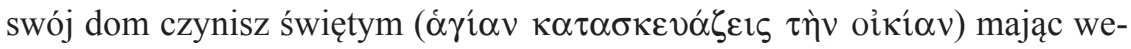
wnątrz złożone zasoby króla"111.

${ }^{110}$ Por. In Matthaeum hom. 66, 4, PG 58, 631, ŹMT 23, 297: „Najpierw więc spłaćmy pod każdym względem ten podatek"; In epistulam II ad Timotheum hom. 1, 4, PG 62, 606; De eleemosyna 3, PG 51, 265, tłum. T. Sinko, Dwadzieścia homilij i mów, s. 103: „Niech każdy w niedzielę odkłada w domu pieniądze pańskie i niech to będzie prawem i zwyczajem niewzruszonym i niech na przyszłość niepotrzebne nam będzie upominanie i doradzanie".

${ }^{111}$ In epistulam I ad Corinthios hom. 43, 1 i 4, PG 61, 368D-369A i 372C-373A. 
„I niech te święte pieniądze razem z prywatnymi leżą w domach, aby i prywatne były przez nie strzeżone. Jak bowiem w kasach cesarskich w razie złożenia w nich pieniędzy któregoś z poddanych, i te korzystają z wielkiego bezpieczeństwa z powodu pieniędzy cesarskich: tak i ty, odłożywszy w domu pieniądze na biednych, zebrane w niedzielę, będziesz w nich miał zabezpieczenie swoich własnych [...]. Niechże wiec w ten sposób dom każdego sta-

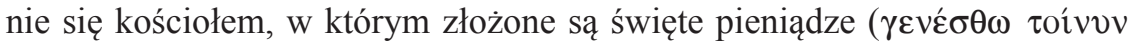

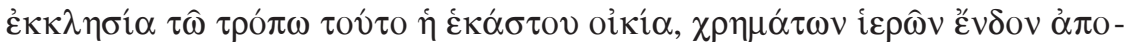
$\kappa \varepsilon \imath \mu \varepsilon ́ v \omega v)$. Albowiem kościelne skarbce są ich symbolem. Miejsce, gdzie leżą pieniądze na ubogich, jest niedostępne dla demonów, i lepiej od tarczy, włóczni, oręża, siły ciała i hufca żołnierzy bronią domów pieniądze zebrane na jałmużnę"112.

Tak więc obok różnych wyżej wymienionych elementów, upodabniających dom - rodzinę do kościoła, jest również według Jana Chryzostoma gromadzona w niej przez domowników jałmużna dla ubogich: ona to bowiem nie tylko uwzniośla modlitwę i zabezpiecza rodzinę przed zakusami szatana, ale ją uświęca i czyni z niej mały kościół.

Podsumowując powyższe uwagi trzeba stwierdzić, że św. Jan Chryzostom wprowadzając pojęcie „Rodzina Kościołem domowym” znajdywał uzasadnienie dla jego semantycznej treści i nazwy przede wszystkim w Dziejach Apostolskich i Listach św. Pawła, gdzie jest mowa o pierwszych wspólnotach chrześcijańskich, gromadzących się w prywatnych domach (co również potwierdzają odkrycia archeologiczne), w których najpierw kwitło życie modlitewno-ascetyczne i prowadzono akcję misyjna, zanim później przeniesiono je do wolnego kościoła, choć podobieństwa i związki między tymi instytucjami zawsze były widoczne. Duży wpływ na wykrystalizowanie się tego pojęcia miała też religijna atmosfera domu żydowskiego, zwłaszcza żyjącego całe wieki w diasporze. Nasz złotousty Kaznodzieja nazywając rodzinę Kościołem domowym chciał do niej przenieść atmosferę kościoła, w którym odprawiano modły i liturgię, śpiewano psalmy, odbywano czuwania nocne, czytano i komentowano Pismo Święte, nauczano prawd wiary, przeprowadzano kolekty dla ubogich, zachęcano do gościnności, w którym wszyscy byli równi realizując przykazanie miłości Boga i bliźniego oraz zdobywając inne cnoty. Wyeksponował przy tym rolę $\mathrm{i}$ autorytet ojca w rodzinie, który na wzór ojca żydowskiego czy rzymskiego pater familias, winien być w niej swego rodzaju przewodzącym modlitwie kapłanem oraz nauczającym prawd wiary i tradycji chrześcijańskich nauczycielem, odpowiedzialnym za życie religijne

${ }^{112}$ De eleemosyna 4, PG 51, 266, tłum. T. Sinko, Dwadzieścia homilij i mów, s. 104-105; zob. Szczur, Problematyka społeczna w późnoantycznej Antiochii, s. 257-259. 
całego swego domu. Pojęcie i nazwa „Rodzina Kościołem domowym” jest oryginalnym tworem Jana Chryzostoma, w starożytności jedynie wzmiankowanym przez św. Augustyna ${ }^{113}$, przypomnianym dopiero w XX wieku przez Sobór Watykański II ${ }^{114}$, używanym przez papieży - Pawła VI (15 razy), Jana Pawła I (2 razy), Jana Pawła II (ponad 300 razy) i Benedykta XVI (dotąd 12 razy) i wielu współczesnych familiologów, którzy jednak wszyscy przypisują jej różne semantyczne treści.

\section{DE FAMILIA CHRISTIANA UTI ECCLESIA DOMESTICA APUD S. JOANNEM CHRYSOSTOMUM}

\section{(Argumentum)}

Dissertatiuncula haec duabus partibus constat. In priore generaliter nomen atque notio locutionis „familia christiana uti Ecclesia domestica”, cuius auctor S. Joannes Chrysostomus invenitur, et quae fundamentum in fontibus biblicis, praesertim in Actis Apostolorum et epistolis S. Pauli Apostoli habet, exponuntur, in altera autem plurimae enuntiationes Episcopi Constantinopolitani, quae familiam christianam Ecclesiae similem faciunt, adducuntur; quae autem in tribus collectae sunt: pater familias domi, sicut episcopus in ecclesia, responsabilis magister veritatum fidei esse debeat; favorabilis locus communis orationis ac religiosi cantus, praesertim psalmorum, esse debeat; in familia christiana, sicut in Ecclesia, omnes familiares pares atque hospitales habeantur et se invicem adiuvare necnon diligere debeant.

${ }^{113}$ Por. Epistula 188, 3, PL 53, 849; De bono viduitatis 23, 29, PL 40, 450; In Joannem tractatus 51, 13, CCL 56, 445; Sermo 94, PL 38, 580-581.

114 Por. Lumen gentium 11; Apostolicam actuositatem 11; Katechizm Kościoła Katolickiego 1656, 1658, 1666; Kompendium Katechizmu Kościoła Katolickiego 350, 456. 